\title{
Fish die-off in river and reservoir: A review on anoxia and gas a supersaturation
}

Correspondence: Angelo Antonio Agostinho agostinhoaa@gmail.com

Submitted January 27, 2021 Accepted May 6, 2021 by Paulo Pompeu Epub July 9, 2021

Online version ISSN 1982-0224 Print version ISSN 1679-6225

\author{
${ }^{\circ}$ Angelo Antonio Agostinho, ${ }^{1}{ }^{\circ}$ Diego Correa Alves ${ }^{1,2},{ }^{\bullet}$ Luiz Carlos Gomes ${ }^{1}$, \\ ${ }^{\circ}$ Rosa Maria Dias ${ }^{1,3},{ }^{\oplus}$ Miguel Petrere $\mathrm{Jr}^{4}$ and ${ }^{\bullet}$ Fernando Mayer Pelicice ${ }^{5}$
}

Albeit massive fish mortality has an extraordinary visual impact and is certainly a fatality, we still have rudimentary understanding on how addressing this problem in the Neotropical region. The processes that lead to fish die-off events are complex and sometimes ephemeral, which can lead to incorrect diagnosis. In this review, we discuss these events in Neotropical freshwaters, both in areas impacted by dams and natural environment, with a focus on deaths mediated by the lack of oxygen (anoxia) or the excess of dissolved gases (gas supersaturation). We examine the available knowledge about the related mechanisms, lethal thresholds for dissolved oxygen (DO) and total dissolved gases (TDG) for fish, and the sequelae of gas bubble disease (GBD). An assessment of the main mortality events in Brazil in the last 10 years is also presented, as well as the best practices for monitoring, prevention, and mitigation. Finally, it is concluded that the proliferation of hydroelectric plants in the Neotropical region might contribute to the expansion of these events and, consequently, increasing of impacts on fish conservation. We consider urgent the inclusion of this topic in the licensing processes for new hydropower projects by the environmental agencies.

Keywords: Dam, Embolism, Fish mortality, Hypoxia, Spillway.

\footnotetext{
1 Programa de Pós-graduação em Ecologia de Ambientes Aquáticos Continentais (PEA), Universidade Estadual de Maringá (UEM). Núcleo de Pesquisas em Limnologia, Ictiologia e Aquicultura (Nupélia), Av. Colombo, 5790, 87020-900 Maringá, PR, Brazil. (AAA) agostinhoaa@gmail.com, (corresponding author), (DCA) dcalves@uem.br, (LCG) lcgomes@nupelia.uem.br (RMD) rmdias2003@yahoo.com.br

2 Departamento de Estatística, Universidade Estadual de Maringá (UEM), 87020-900 Maringá, PR, Brazil.

3 Programa Nacional de Pós-Doutorado PNPD/CAPES.

4 Programa de Pós-Graduação em Sustentabilidade de Ecossistemas Costeiros e Marinhos (PPG - ECOMAR), UNISANTA Rua Oswaldo Cruz, 277, Boqueirão, 11045-907 Santos, SP, Brazil. Present address: Núcleo de Ecologia Aquática e Pesca da Amazônia (NEAP), Universidade Federal do Pará (UFPA). Avenida Perimetral, 2651, Guamá, 66077-830 Belém, PA, Brazil. mpetrerejr@gmail.com

5 Núcleo de Estudos Ambientais (Neamb), Universidade Federal do Tocantins (UFT), Rua 3, Quadra 17, Jardim dos Ipês, 77500-000 Porto Nacional, TO, Brazil. fmpelicice@gmail.com
} 
Embora mortandades massivas de peixes tenham impacto visual extraordinário e sejam certamente uma fatalidade, estamos ainda engatinhando no entendimento e na solução desse problema. Os processos que levam aos eventos de mortes de peixes são complexos e algumas vezes efêmeros, o que explica diagnoses incorretas. Nessa revisão nós discutimos esses eventos em bacias hidrográficas neotropicais, tanto em barragens como em ambientes naturais, porém com o foco nas mortes por falta de oxigênio (anoxia) ou excesso de gases dissolvidos (supersaturação gasosa). Em particular são examinados o conhecimento disponível acerca dos processos que levam a essas condições, os limiares letais de oxigênio dissolvido (OD) e gases totais dissolvidos (GTD) para os peixes e as sequelas da doença das bolhas de gás (DBG). Uma avaliação dos principais eventos de mortandade que ocorreram no Brasil nos últimos 10 anos é também apresentada, bem como discutidas as melhores práticas para o monitoramento, prevenção e mitigação. Conclui-se, finalmente, que a proliferação de hidrelétricas deve contribuir com a expansão desses eventos e consequentemente com mais um fator de ameaça à biodiversidade. Consideramos urgente a inclusão desse tema nos processos de licenciamento de novos empreendimentos pelo órgão ambiental.

Palavras-chave: Barragem, Embolia, Hipoxia, Mortandade de peixes, Vertedouro.

\section{INTRODUCTION}

Massive mortality of fish are common events in hydroelectric plants, but their relevance as impacting fish conservation varies widely (Agostinho et al., 2007). The main difficulties faced by both the hydroelectric sector and environmental agencies entail identifying the drivers that determine these episodes and their effects on fish fauna and fishing activities. The success of prevention measures depends on understanding how fish interact with dams and reservoirs, which is complicated by the existence of many variables and multiple interactions. Fish deaths are, in general, associated with the design and operation of the dam's hydraulic structures and the characteristics of the local biota (i.e., composition, abundance, and life strategies), in addition to environmental features (i.e., climatic conditions and topography). Thus, each fish mortality/injury event may be due to different causes, new interactions, or circumstantial situations, such as the water level downstream or the abundance, composition, and location of the fish assemblage in the vicinity. These variations hinder reliable predictions about fish mortality events and explain the lack of operational protocols to prevent this problem. At the same time, failures to identify the cause of fish mortality events enable such events to recur, even if mitigation measures are taken routinely.

Fish deaths below dams can result from a range of sources (Agostinho et al., 2007; Andrade et al., 2012; Godinho, Loures, 2016). These include (i) shocks with hydraulic structures or adverse hydrodynamic conditions, including turbulence, shear forces, cavitation, or sudden changes in hydrostatic pressure. The (ii) confinement of shoals inside generating unit components, such as the draft tube, spiral case, and drain well, is also a significant source of fish death and injury. Moreover, (iii) sudden variations 
in the downstream level, which can result in the retention of shoals in small pools, (iv) poor water quality released by spillway or turbines, and (v) gas supersaturation, may have deleterious effects on fish and cause mass mortality. With the exceptions of (i) above, the effects of these factors are mediated by anoxia or gas supersaturation. Fish entrance in the turbine, followed by confinement and establishment of hypoxia or even anoxia condition, is likely the main cause of fish deaths in Brazilian dams (Andrade et al., 2012; Godinho, Loures, 2016; Rêgo et al., 2016). Turbines that stop or start while the downstream gate is still open may allow shoals to enter and trap fish in the draft tube or other compartments. Depending on the size of the shoal and water temperature, oxygen demand may increase quickly, creating anoxic conditions and causing massive death.

Some reviews have systematized knowledge about fish deaths in dams located in temperate regions, especially North America (Cada et al., 1997; Algera et al., 2020). Studies that explore fish mortality associated with gas supersaturation also focus on events of temperate latitudes (Weitkamp, Katz, 1980; Pleizier et al., 2020), with about $87 \%$ of the articles evaluating the response of the Salmonidae family. Deaths due to hypoxia or anoxia, on the other hand, are reviewed in the context of responses and physiological and behavioral adaptations at different levels of organization (Ultsch, 1989; Val et al., 1995, 1998; Pollock et al., 2007; Val, 2017). In the Neotropical region, fish deaths have been reported in hydroelectric dams (Agostinho et al., 2007; Loures, Godinho, 2016), but information remains dispersed and poorly understood. To organize existing data and generate information relevant to the management of dams in South America, we provide an overview of fish mortality and injuries in hydroelectric dams with special emphasis on the roles played by oxygen concentration (DO) and total dissolved gas supersaturation (TDGS). In this review, we detail the processes that lead to conditions of anoxia and gas supersaturation in hydroelectric dams, the risks involved, the responses of fish species, and some preventive or mitigating actions. Moreover, we investigate the response of freshwater fish to variations in oxygen concentrations in natural environments, as Neotropical fish have evolved different mechanisms to cope with variations in oxygen concentration in the aquatic environment. Finally, we search for information about fish mortality in areas affected by hydropower plants in Brazil to describe these events, identify their potential causes, and determine their impact on Neotropical fishes.

\section{WHEN THE MAN IS NOT GUILTY: FISH DEATH IN NATURAL ENVIRONMENTS}

Anoxia and gas supersaturation are extreme conditions frequently observed in areas affected by hydroelectric dams; however, they also occur in pristine natural environments when specific conditions coalesce. Understanding the phenomena under natural conditions is important to depict the mechanisms that cause deaths in areas impacted by dams. Such an understanding can serve as a baseline for environmental impact studies, since hypoxia or anoxia are similar under natural and anthropized conditions. In this section, we investigate the occurrence of hypoxia and anoxia in natural environments and the response of fish to these conditions, which sometimes result in fish death. 
Hypoxia and anoxia. Although many species can tolerate short periods of anoxia, dissolved oxygen is critical for fish survival (Val, 2017). In general, fish avoid environments whose oxygen concentrations fall below certain thresholds. Nevertheless, some reports suggest that certain species may select these environments as fruitful locations to search for food (Rahel, Nutzman, 1994; Matthews, 2003), making use of behavioral, physiological, or morphological adaptations developed throughout their evolutionary histories (Kramer et al., 1978; Winemiller, 1989; Fernández-Osuna, Scarabotti, 2016).

Hypoxia can be defined based on different criteria, such as dissolved oxygen concentration (<2.0 mg/L; Chesney et al., 2000), saturation level (any below 100\%; Timmerman, Chapman, 2004), or even any level of dissolved oxygen that is sufficient to negatively impact the behavior or physiology of an aquatic organism (Pollock et al., 2007). Hypoxia and anoxia are natural phenomena recorded in aquatic ecosystems around the world; emblematic examples include floodplains in the tropics and frozen lakes at high latitudes. However, human behavior has aggravated these natural conditions via pollution with urban, industrial, and mining effluents, changes in hydrological connectivity, and other actions that lead to global warming (Chesney et al., 2000; Diaz, 2001; Pollock et al., 2007)

Natural events, such as seasonal variations in the river levels during years with exceptional droughts or floods, can lead to the confinement of fish in small water bodies and/or to the incorporation of a large amount of plant biomass, which can affect the oxygen concentration by decomposition and biota consumption, aggravated by high temperature. Such events are common in floodplains, especially during the flood retreat periods. These periods can result in the retention of many fish in remaining bodies of water, such as floodplain lakes. The high biomass of fish confined in these bodies of water, their high levels of oxygen consumption, the demands of the decomposition of the flooded organic matter, and the adverse effect of high temperatures generate conditions of hypoxia or even anoxia and, ultimately, promote massive fish deaths. This process can occur during flooding or at the beginning of flood retraction, as a result of the high consumption rates of heterotrophic processes linked to the decomposition of the flooded organic matter ("dequada"; Calheiros et al., 2000). However, it can also occur closer to the end of the flood retraction period, when the isolated lakes are destratified and the anoxic or severely hypoxic conditions of deeper layers mix in the water column ("friagem"; Esteves, 1998). Fish deaths resulting from these events are common in the Pantanal and the Amazon. Exceptional droughts also promote massive deaths, concentrating fish in very shallow bodies of water.

Because periodic floods in river-floodplain systems, such as in the Pantanal and the Amazon, are natural and predictable seasonal events, fish have developed different adaptive strategies to cope. These selective pressures that act on fish confined in small water bodies during the drought period in floodplains are also reported for the Paraná River (Cunico et al., 2002) and São Francisco River (Pompeu, Godinho, 2006) basins. Indeed, many of the fish fauna living in these habitats display a certain sensitivity to variations in the physical and chemical conditions and decreasing river water levels (currents, pressure, oxygen, and temperature) and, thus, avoid such conditions or environments. These early perceptions enable fish to abandon these habitats before they lose their connection with the rest of the system (Lowe-McConnell, 1986). On 
the other hand, species that manage to survive in these environments (via accessory breathing or tolerance, for example) can benefit from the accumulation of prey and thereby increase their fitness (Petry et al., 2013).

To face the problems of hypoxia, some species resort to adaptations such as physiological tolerance, aerial breathing, and surface aquatic breathing, or the use of the better oxygenated upper layer of the water column. These measures allow survival in aquatic habitats with low levels of dissolved oxygen (Kramer et al., 1978; Winemiller, 1989; Val et al., 2015). The survival of trahira (Hoplias microleps (Günther, 1864)) for a short time under total anoxia has, for example, been reported in the literature (Dickson, Graham, 1986). Physiological adaptations, like tolerance to hypoxia, have been demonstrated for several other Neotropical species, such as trahiras (Rantin, Johansen, 1984) and tambaqui Colossoma macropomum (Cuvier, 1816) (Saint-Paul, Soares, 1987), among others (Salvo-Souza, Val, 1990; Brauner et al., 1995). Aerial breathing, performed via organs modified by intense blood irrigation such as a swimming bladder, gill chamber, gills, buccopharyngeal epithelium, or stomach, is also common among Neotropical fish (Val, Almeida-Val, 1995). These adaptations are present in about $25 \%$ of fishes that use floodplain lakes (Winemiller, 1989). However, surface aquatic respiration (SAR) is considered the main behavior by which many species without accessory respiratory adaptations survive prolonged periods of hypoxia (Kramer, 1987; Winemiller, 1989). To engage in SAR, some fish develop fleshy, highly irrigated lip protuberances, which they position on the better oxygenated surface of the water column (water-air interface). These protuberances disappear when water oxygenation increases, as shown by the experimental data obtained from pacu (Piaractus mesopotamicus (Holmberg, 1887)) and reported by Fernández-Osuna, Scarabotti (2016).

Winemiller (1989) and Fernándes-Osuna, Scarabotti (2016) have devoted considerable studies in identifying the thresholds of dissolved oxygen concentration that lead to biological responses among Neotropical species. For example, FernándezOsuna, Scarabotti's evaluation (2016) of the behavioral and physiological responses that accompany the morphological changes (irrigated protuberances) of pacu revealed that oxygen concentrations below $2.5 \mathrm{mg} / \mathrm{L}$ result in an increased respiratory rate. The displacement to the surface, which also begins in waters with these concentrations, is only complete when oxygen concentration is below $1.0 \mathrm{mg} / \mathrm{L}$. Horizontal displacements tend to increase as dissolved oxygen approaches zero, while vertical movements cease when dissolved oxygen falls below $1.0 \mathrm{mg} / \mathrm{L}$. Lip and jaw protrusions in fish were observed only in environments with surface water concentrations below $1.4 \mathrm{mg} / \mathrm{L}$ and bottom water concentrations of $0.8 \mathrm{mg} / \mathrm{L}$ (Winemiller, 1989). The development of the opercular valve, which is more closely related to the hyperventilation of gills, occurs under dissolved oxygen concentrations from 2.5 to $1.7 \mathrm{mg} / \mathrm{L}$ (Fernández-Osuna, Scarabotti, 2016). It is noteworthy that these values vary considerably between species (Agostinho et al., 2007; Small et al., 2014).

An important aspect in the evolution of conditions from normoxia to hypoxia and anoxia is the time required for oxygen levels to fall and the time required for fish to respond with their physio-morphological strategies. Thus, the manifestation of this adaptation may not be immediate. Unlike tolerant species or those with special organs for air breathing, fish that depend on SAR require time to adapt. If oxygen depletion towards anoxia occurs at a higher rate than the development of these morphological 
structures, death may occur. Experiments involving pacu show that under surfacelevel dissolved oxygen concentrations of $0.4 \mathrm{mg} / \mathrm{L}$, the percentage of lip increase is approximately 30\% after one hour, reaching the highest percentage of development (120\%) after five hours (Saint-Paul, Bernardino, 1988).

Total Dissolved Gas Saturation. Dissolved oxygen levels can vary widely in space and time, demanding physiological and behavioral plasticity from organisms (Val et al., 2015). Anoxic conditions can progress to hyperoxia in a period of 24 hours in the same environment (Val, 2017) or between close environments, i.e., river channel and marginal lake (Roberto et al., 2009). In fact, saturation values above $120 \%$ are common in river channels, below waterfalls, and in lentic or semi-lentic bodies of water with high algal densities. In the latter case, saturation essentially involves oxygen (hyperoxia) derived from high primary productivity (photosynthesis), while in the former, saturation results from the incorporation of atmospheric air bubbles that are carried to the bottom of the body of water where, under condition of high hydrostatic pressure, they are dissolved. In this case, dissolved gases are essentially nitrogen and oxygen. Studies of these events in natural environments reveal that although scarce elsewhere, they are particularly frequent downstream of large waterfalls. It is not known, however, the extent or importance of these events for fish populations or the differences in susceptibility between species to these conditions. Baird et al. (1999) report that artisanal fishermen from the Mekong River who fished downstream of the Khone Falls (Southern Lao) used to keep the fish alive in marginal water bodies and not in the river channel. In fact, experiments that kept fish of various species downstream of the main waterfall reported faster deaths than those that kept fish downstream of other smaller falls or rapids (Baird et al., 1999). It is noteworthy that studies have recorded no deaths of wild fish due to gas supersaturation below natural waterfalls. This fact is relevant, especially when considering the stretch of the Mekong River where the Khone Falls flows, as it sustains one of the most important and productive fisheries in Southeast Asia (Baird et al., 1999). Downstream of the Khone Falls, fish are occasionally seen floating lifeless and adrift but with unknown cause of death. Some segments of the waterfall transects serve as fish passages during migratory movements (Roberts, Baird, 1995), and certainly to reach them, migrants must pass through supersaturated waters. The absence of death events in this region may be explained by the escape from more adverse environments, the moderate gas saturation levels in most of the area, and the rapid displacement of migrants through stretches with greater saturation (Baird et al., 1999).

Oxygen supersaturation can also have its origins in physical (temperature) and biological processes as well, which are generally restricted to the surface of the water bodies (Esteves, 1998). The combination of these processes can create a lethal environment for fish. Nevertheless, as mentioned before, changes in these conditions are gradual, allowing fish to detect them and leave the area (Miranda et al., 2000). Thus, conditions of hyperoxia caused by macrophytes or algal blooms are commonly observed affecting surface waters during the day (Pelicice et al., 2005). It should be noted that when the bottom waters are hypoxic, the surface waters are used by many species to extract oxygen (Miranda et al., 2000). Moreover, macrophyte stands represent important shelters and feeding sites for fish. Hyperoxic and hyperthermic conditions on the surface, especially in the late afternoon, may lead fish to abandon shelters or feeding 
sites, descending further below the surface or escaping to open areas when possible. Miranda et al. (2000) report that macrophyte stands can, for example, increase the upper half of the water column to very high concentrations of oxygen (up to $20.0 \mathrm{mg} / \mathrm{L}$ ) and saturation levels above $300 \%$, especially at dusk. On the other hand, the bottom of the body of water may exhibit oxygen levels close to zero. In this case, fish seek the intermediate zones for survival, sometimes depriving themselves of shelter, adequate food, and protection against predation.

\section{WHEN THE MAN IS GUILTY: FISH DEATH IN DAMS}

Hypoxia and anoxia. Consistent with environmental impact study findings, studies on anoxia and fish deaths in dammed rivers have been conducted mainly in the impoundment area. Several cases of anoxia, which can occur during reservoir filling or soon after, have been associated with the decomposition of organic matter, especially via labile material such as grasses, herbaceous plants, and litter (Bianchini et al., 1998; Cunha-Santino et al., 2002; Agostinho et al., 2007). The excess of organic matter typically leads deep layers of the reservoir to conditions of hypoxia or even anoxia. The extent of these conditions and their persistence are linked to the dynamic of the reservoir flow, which depends on the type of operation (run-of-river; accumulation) and position of the water intake, being larger in stretches of flooded tributaries. Because the demand for oxygen is high during the early years of the impoundment, the duration of this phenomenon is also related to the age of the reservoir. After the early period of impoundment, low oxygen concentrations are limited to deeper layers of the water column, mainly in reservoirs with strong vertical stratification.

The proliferation of dams promotes the expansion of areas in the basin that are subjected to eutrophication, anoxia, and fish death. Among the events that lead to this scenario, several stand out: (i) the change in the water retention time, transforming lotic stretches of the basin into lentic areas, (ii) restrictions imposed by thermal stratification in water circulation, and (iii) the releasing of organic matter and nutrients by human activities in the catchment basin as urban, industrial, and agricultural effluents. Eutrophication, one of the most prevalent and widespread problems in freshwater worldwide (Rivas et al., 2020), results from the input of nitrogen and phosphorus that intensifies primary production and results in the excessive proliferation of algae and aquatic macrophytes (Esteves, 1998; Diaz, 2001; Tundisi, Tundisi, 2008). The proliferation of cyanophyte algae and dinoflagellate has been responsible for hypoxic or even anoxic conditions, especially at the bottom of reservoirs. Daily vertical displacement of fish has also been considered an adaptive behavior to avoid hypoxic conditions at the bottom of reservoirs (Prado, Pompeu, 2017). The restoration of water circulation, due to a drop in temperature or strong winds, can produce massive fish deaths.

However, the most frequent sources of fish death from anoxia are linked to the retention of fish in the draft tube of the generating units (Agostinho et al., 2007; Loures et al., 2016a), causing major mortality events downstream dams. These events begin when, during the turbine stops but before the gates are closed, fish are attracted from the tailrace into the draft tube and other generating unit compartments. The severity of the event depends on the number of fish retained and the time required to rescue those trapped or reopen the gate (Agostinho et al., 2007). Fortunately, these processes are 
subjected to extensive monitoring and control (Loures et al., 2016b), and many plants perform complex maintenance and rescue operations to remove fish from generating units.

When the stretch downstream of the dam is irregular or its bed has a steep slope, the intermittent operation of the dam's hydraulic structures, due to variation of the daily demands for electricity, can result in the formation of isolated and semi-isolated pools or very shallow stretches. Thus, stretches with high gradients and irregular water flows can attract fish, which, with the interruption of the water flow, become trapped in pools, increasing mortality from predation and/or anoxia. In addition to the daily decrease in discharge motivated by a reduction in energy demands, downstream level can be severely affected by total interruption of the flow due to unexpected problems in the transmission system (trip events) that produces a sudden drop in the downstream river level, which may persist until the flow is restored, by spillway or turbine.

The possibility of fish deaths in these isolated pools during such circumstances is high. Several factors determine the severity of this phenomenon, such as the number of fish trapped in the pools, the consequent demand for oxygen, the concentration of this element in the turbined water, and the time required to restore the flow and connectivity of the pools. Under extreme conditions, these events can be extremely quick and disastrous (Agostinho et al., 2007). In fact, they are often so ephemeral that their origin can only be detected in surveys analyzing the operational procedures of the hydraulic structures on a fine time scale (less than one hour). With oxygen scarcity, the fish, while alive, concentrate on the surface of the pools; when dead, they can be seen floating, usually with open mouths and opercula. Similar events may later occur upstream of the dam, when sudden changes in the level of the reservoir create marginal pools, which retain fish for varying periods. The desiccation of these pools or the establishment of anoxic conditions cause these fish to die (Rêgo et al., 2016).

Anoxia caused by effluent water from the reservoir can also affect the downstream section (tailrace and further downstream) and result in fish deaths. This occurs especially when the water intake is positioned in the hypolimnion, draining water with low or even anoxic concentrations of oxygen. However, fish mortality events as a result of this process are rare, mainly due to (i) the early detection of hypoxia and subsequent escape of fish from the area, (ii) tolerance to hypoxia or morphophysiological adaptations to cope with these conditions (see previous section), and (iii) the mixture of turbine and spillway water when both hydraulic structures are operating and the local topography facilitate it.

\section{GAS SUPERSATURATION}

Origin of TDGS and dissipation

Total dissolved gas supersaturation (TDGS) occurs when the pressure of atmospheric gases in solution in the water exceeds that of the local barometric pressure (Weitkamp, 2008; Wang et al., 2020). The impact of TDGS on aquatic biota has been reported since 1898, when the results of studies carried out by Gorham at the Woods Hole Oceanographic Institute in Massachusetts were published (Gorham, 1900). However, research on TDGS accelerated only in the 1960s, when researchers found that spillway operation at Columbia River plants were killing fish and threatening salmonid stocks (Cao et al., 2016; Pleizier et al., 2020). The risks posed by this phenomenon on river 
ecosystems have become a global environmental concern (Witt et al., 2017; Ji et al., 2019), with an extraordinary increase in publications in recent decades, especially those related to hydroelectric dams from China and Southeast Asia. Although a reasonable number of studies about fish tolerance to supersaturation exist, important gaps concerning development phases (Wang et al., 2020), species, and fish size (Cao et al., 2016; Ji et al., 2019; Fan et al., 2020) remain.

Gas supersaturation may be a condition of the water present in the tailrace as a result of the extraordinary operation of the turbines (e.g., synchronous operation). However, this is a typical spillway phenomenon, associated primarily with its design and operation, and the turbines generally do not contribute to the production of TDG (Feng et al., 2018; Wan et al., 2020). The spillway is a hydraulic structure designed to manage water from the reservoir, protect the dam from flooding, and restore the flow downstream the dam when the turbine flow is insufficient. Although present in all hydroelectric dams, the frequency with which the spillway is activated depends on the capacity of the plant and the affluent flow. If the turbine capacity exceeds the affluent flow, the spillway's operation can be sporadic. In those reservoirs with low storage capacity, spillways are used more frequently, especially during the interruption of turbines, whether deliberate (insufficient water, scheduled maintenance) or not (problems with transmission lines, electromechanical problems). Thus, spillways are widely variable in design, location, number, water intake, and operation (Agostinho et al., 2007). In fact, some spillways are not controllable (without a gate), and the excess flow is released by a free sill. In this case, the flow changes are gradual as in a natural waterfall, thus expecting a lower chance of causing problems.

During spillway operation, water from the reservoir will get bubbles of atmospheric air, which is common to spillways with emerged or semi-submerged floodgates, is released downstream. At the bottom, under conditions of high hydrostatic pressure (> 2 atmospheric pressure), the air bubbles are dissolved, and the stream of supersaturated water is conducted downstream (Hibbs, Gulliver, 1997; Li et al., 2009; Lu et al., 2019) (Fig. 1). The condition of total dissolved gas supersaturation (TDGS) persists at variable distances from the dam and may reach $180 \mathrm{~km}$ downstream $(\mathrm{TDG}=128 \%)$ in the Yangtze River below Three Gorges Dam (Feng et al., 2010; Liu et al., 2019). Some authors record distances up to $500 \mathrm{~km}$ (Chen et al., 2009; Shen et al., 2016).

Gas supersaturation conditions are achieved when the total gas pressure (TGP) in a body of water exceeds the compensation pressure (CP). TGP is defined as the sum of the pressures of the gases present, and CP is equal to barometric pressure (dependent on altitude and weather conditions) plus hydrostatic pressure (dependent on depth; about $76 \mathrm{mmHg} / \mathrm{m})$. The pressure difference $(\triangle \mathrm{P}=\mathrm{TGP}-\mathrm{CP})$ becomes a determinant of supersaturation only when greater than zero (Schisler, Bergersen, 1999).

A different origin can produce supersaturation in man-made lakes or ponds for fish farms. In these habitats, Boyd et al. (1994) report that before dawn, water is saturated with Nitrogen $\left(\mathrm{N}_{2}\right)$ and Argon (Ar), unsaturated with dissolved oxygen (DO), and supersaturated with carbon dioxide $\left(\mathrm{CO}_{2}\right)$. In the afternoon, they detect supersaturation of DO (phytoplankton photosynthesis) and, to a lesser extent, $\mathrm{N}_{2}$ and Ar. These authors attribute the supersaturation of $\mathrm{N}_{2}$ and $\mathrm{Ar}$ to the heating of the cooled water saturated with atmospheric air during the night (Boyd et al., 1994). In a similar way, cooling water used in thermal and nuclear power plants can also generate gas saturation conditions. 


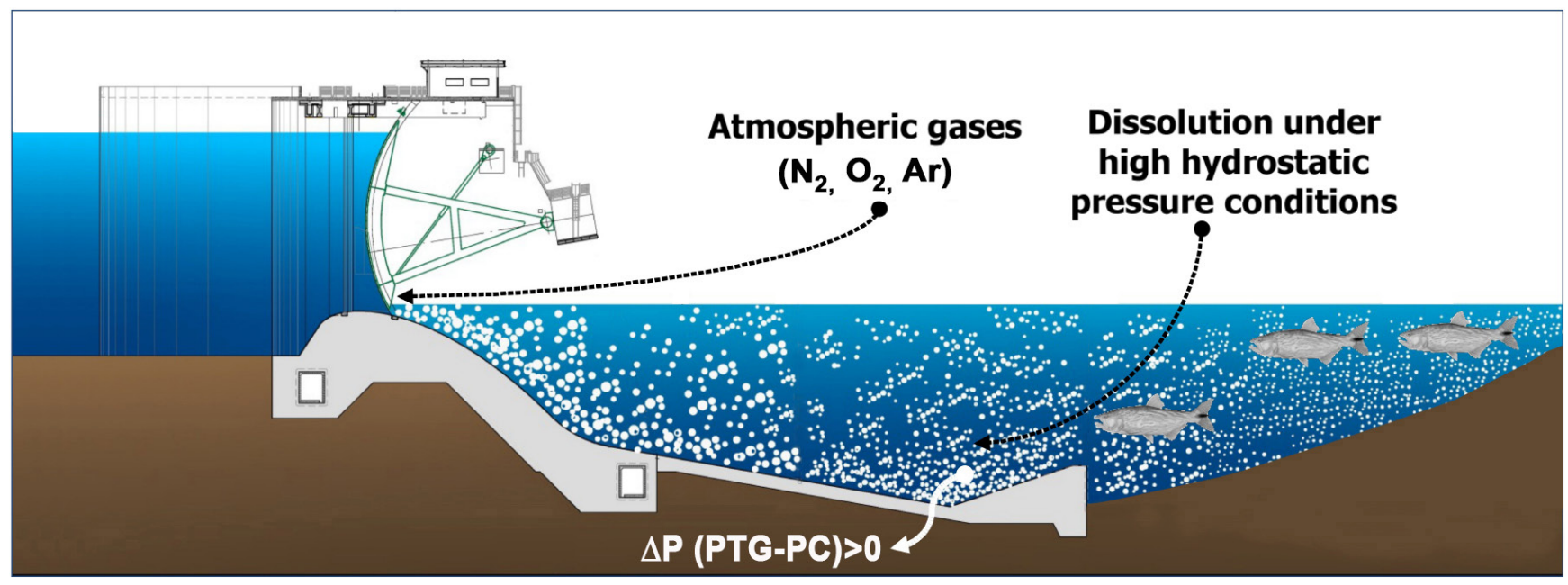

FIGURE 1 I Processes involved in gas supersaturation at downstream a spillway. PTG = Total gas pressure, PC = Compensation Pressure (barometric + hydrostatic) - (modified from Abernethy et al., 2001).

\section{TDGS THRESHOLDS, DETECTION AND AVOIDANCE}

Critical TDGS threshold values for fish are quite controversial. In terms of water quality, the United States Environmental Protection Agency (EPA) limits this value to $110 \%$ saturation $(\Delta \mathrm{P}=76 \mathrm{mmHg}$ at sea level). However, this value has been considered high by some researchers, since at this level, prolonged exposure can lead to death, especially in restricted shallow water environments (Bouck, 1980). Others believe that this threshold is low, since fish can, by escape, avoid adverse conditions (Schisler, Bergensen, 1999). Regardless of the specific limit, a widespread understanding prevails that TDG saturation levels above 125\% are lethal (Fidler, Miller, 1994; Cao et al., 2016, 2020; Deng et al., 2020), while TDGS levels of $120 \%$ have been considered non-lethal in laboratory experiments (Huang et al., 2010; Cao et al., 2016). Deng et al. (2020) likewise report that no fish subjected to chronic exposure at $115 \%$ died in their experiments; however, the same fish exhibited light signs of gas bubble disease (GBD), and when these fish were exposed to higher values, they were less tolerant (Deng et al., 2020).

Fish have the ability to detect and avoid areas with high saturation of dissolved gases (Chen et al., 2012; Wang et al., 2015; Shen et al., 2016). Heccbercet (1984) first reported this adaption, recording significant deaths among fish kept in cages under conditions of TDGS up to $180 \%$ but no fish deaths in river water with TDGS up to $180 \%$ (Cao et al., 2016). The presence of refuges, represented by deep waters and the entry of less oxygenated waters from turbines and side tributaries, are fundamental for fish survival in conditions of high TDGS. As the saturation of total dissolved gases depends on the hydrostatic pressure, the same concentration of these gases in the column presents lower saturation values in deep layers (depth compensation), which can serve as highly effective fish shelters (Weitkamp et al., 2003; Weitkamp, 2008; Xue, 2019). It is estimated that TDGS decreases about $10 \%$ every meter between the surface and the bottom (Weitkamp et al., 2003). Experiments show that even if the fish do not respond 
to total dissolved gas saturation in concentrations below 125\%, they can detect higher TDGS and use depth compensation, descending between 2.5 and $3.3 \mathrm{~m}$ (Wang et al., 2020). It is noteworthy, however, that fish have different abilities to detect and avoid high TDG saturations, and therefore, not all are able to utilize depth compensation efficiently (Cao et al., 2016).

\section{GAS BUBBLE DISEASE (GBD)}

Atmospheric gases dissolved in the water (essentially $\mathrm{N}_{2}, \mathrm{O}$, and Argon) penetrate aquatic organisms by diffusion and reach points of microscopic nucleation in cavities of the animals' bodies. There, they form bubbles, which are carried by circulation to all parts of the body. In the vital organs, these bubbles can cause embolism (in the vascular system) and emphysema (in other tissues), leading to neurological, vascular, respiratory, and osmoregulation disorders (Agostinho et al., 2007). When an animal ultimately dies from a gas embolism, the pathology is known as gas bubble disease (GBD). In an experiment, fish exposed to high TDGS initially exhibited abnormal and erratic behavior, with rapid breathing, rapid swimming, and an agitated escape response (Liu et al., 2019), which can increase the risk of injury (e.g., scratches, lesions, scraping, abrasions, fractures) in environments with high turbulence, such as the plunge pool and its surroundings.

A simple visual inspection can identify fish that recently succumbed to embolism, as they exhibit small air bubbles under the integument (Fig. 2A), inside the eyeball (Fig. 2B), along the rays of the fins (Figs. 2C, D, E), in the gill filaments (Fig. 2F), in the circulatory system in general (Cao et al., 2019). However, these signs can disappear quickly after fish death as these gases diffuse with the loss of blood pressure. The sequelae, which occur when TDGS levels are high, persist for longer as hemorrhages and tissue necrosis (Stroud et al., 1975; Xue, 2019), infections (Stroud et al., 1976), exophthalmos (Figs. 2A, B), positive buoyancy (Shrimpton et al., 1990; Xue, 2019), collapse of the swim bladder and change in behavior (Lund, Heggberget, 1985), or even bubbles in the eyeball (Fig. 2).

The factors affecting the severity of TDGS effects on fish can be classified into two groups: intrinsic, including body size, stage of development, species, and behavior, and extrinsic, comprising depth, water temperature, turbulence, and oxygen-nitrogen ratio (Cao et al., 2019; Ji et al., 2019; Pleizier et al., 2020). Other extrinsic factors related to GBD severity are the exposure time, the concentration of suspended solids (Ji et al., 2019; Feng et al., 2019), and the intermittent exposure to gas supersaturation (Cao et al., 2016). In the latter case, it should be noted that grass carp Ctenopharyngodon idella (Valenciennes, 1844) exposed to the single acute condition of gas supersaturation are less vulnerable than those subjected to multiple exposures (Ji et al., 2019), and the same trend was recorded by Fan et al. (2020) for another carp Schizothorax prenanti (Tchang, 1930). On the other hand, Chinese sucker facing intermittent exposures (Myxocyprinus asiaticus (Bleeker, 1864)) exhibit significantly increased survival time compared to those facing continuous exposure (Cao et al., 2016).

In addition to embolisms that result from gas supersaturation in the spillway, fish can also be injured when they enter and pass through this structure and its associated plunge pool. However, dragging fish through the spillway is not the most relevant 

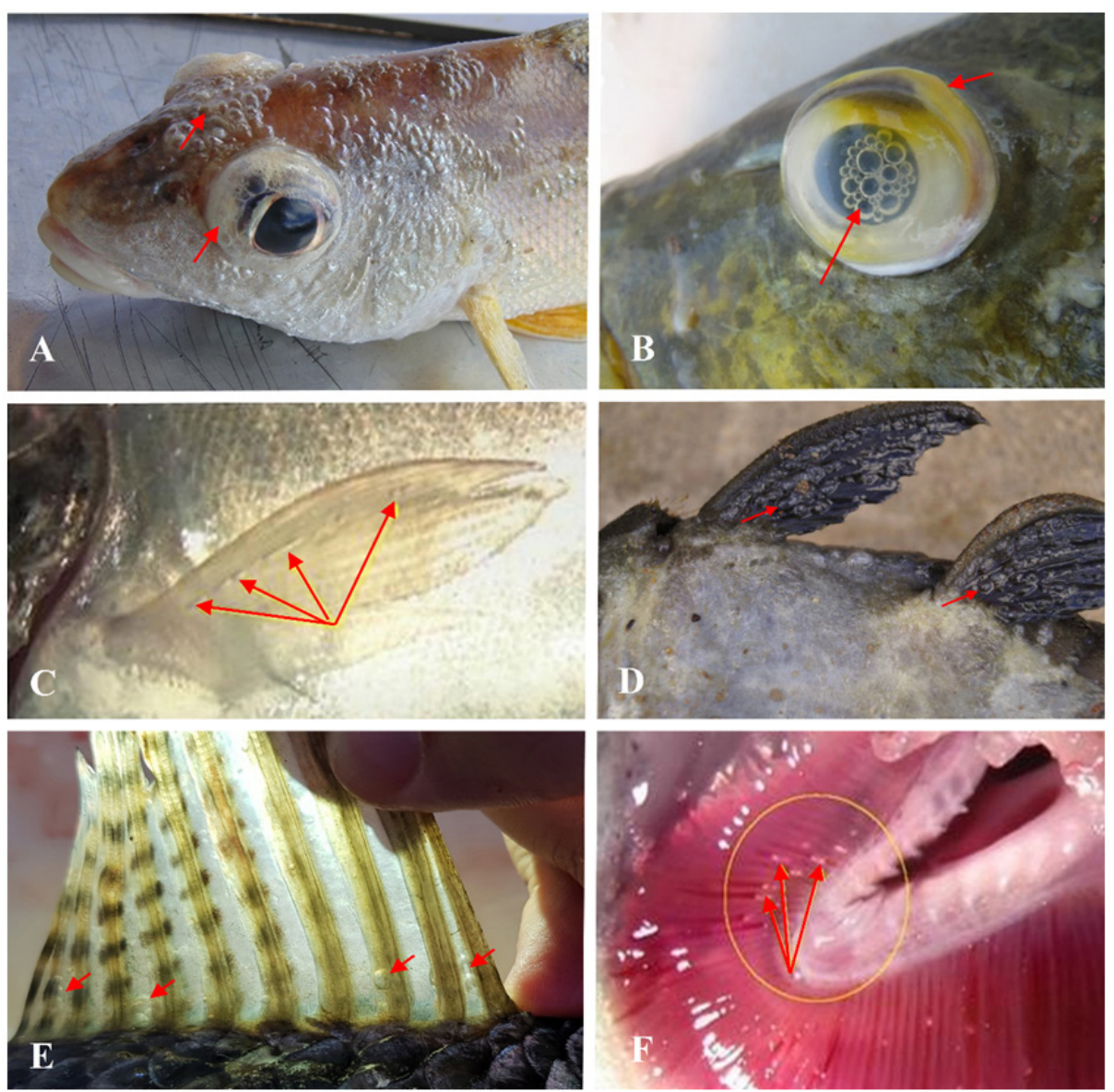

FIGURE 2 I Indication of gas bubble disease in fish downstream from spillways, with bubbles in integument (A), eyeball (B), exophthalmos $(\mathbf{A}, \mathbf{B})$, along with the rays of the pectoral $(\mathbf{C}, \mathbf{D})$ and dorsal fins $(\mathbf{E})$ and in the gill filament $(\mathbf{F})$.

source of death for these animals in dams; deaths caused by fish passage through the spillway, while possible, are much less common than those from passage through the turbines. In fact, survival rates for fish passing through the spillway are so high that it is considered the best structure for downstream passage of salmon in the Northern Hemisphere (Agostinho et al., 2007).

\section{TDG IDENTIFICATION AND MEASUREMENTS}

The attribution of fish mortality to gas supersaturation is difficult because the process is ephemeral, both in the aquatic environment and in the body of the fish. Thus, changes in the water flow rate can result in the instantaneous disappearance of supersaturation without the possibility of detection in subsequent surveys. For example, supersaturation is expected to occur in certain ranges of spillway operation (critical operation), as seen in the mid-Columbia River hydropower system (Witt et al., 2017) and other dams in the Lower Columbia River (Bragg, Johnston, 2016). However, spillway gates that remove the operation from this critical range suddenly interrupt this source of disturbance and its manifestations. When the spillway is closed, water released from the turbine, generally 
with a low oxygen concentration, can rapidly spread throughout the tailrace and produce mistaken conclusions about the "causa mortis." In fact, the association of supersaturation with fish deaths in dams in South America is restricted to some dams in the Amazon basin and the São Francisco (Gama, 2020; see next topic) and to the Yacyretá Dam in the Argentine stretch of the Paraná River (Domitrovic et al., 1994, 2000; Bacchiega, Fattor, 2004). Other occurrences of fish mortality in hydroelectric dams likely derive from gas supersaturation as the main cause but were not reported or recognized as such, probably due to the aforementioned ephemeral character of gas supersaturation in the environment. This aspect also makes necropsy difficult, given the rapid loss of biological signs of embolism in the first hours after death, especially when gas supersaturation is weak. An exception is the sequelae left by more severe events (AAA, pers. obs.). Outside of these exceptions and in the absence of constant monitoring, it is difficult to confirm the role of gas supersaturation in fish mortality events.

The continuous monitoring of gas saturation, essential to prove its effects on fish mortality, is also important to reveal the mechanisms that provoke supersaturation. Constant monitoring of the operation of the dam's hydraulic structures enables scientists to identify the critical ranges for the manifestation of this supersaturation. In this sense, constant monitoring of gas saturation, spillway operation, and upstream and downstream water level is essential. It is noteworthy that continuous data is defined here as those taken at short intervals (at maximum intervals of $3 \mathrm{~min}$ ). Data on dam operation and hydraulic control are easily obtained via the operation control systems, requiring only an adequate recording and storage routine. Gas saturation data, on the other hand, are more unusual, especially in dams in the Neotropical realm.

Gas saturation data can be more adequately obtained using TDG measurement devices or a saturometer (q.v. tab. 2 in Ma et al., 2013). However, many researchers use dissolved oxygen saturation as a proxy to determine TDG concentrations in water, since TDG probes are more expensive than conventional oxygen saturation gauges and also less available in South American markets (Ma et al., 2013). In Brazil, routine monitoring of reservoirs does not entail total dissolved gas saturation, as it is not listed as a water quality parameter in the National Council for the Environment (CONAMA) resolutions, nor is it among the risk factors in environmental impact assessments.

Nonetheless, criticisms are raised regarding the use of oxygen saturation as a proxy for TDGS. Li et al. (2013) compared the parameters involved in the DO and TDG dissipation and reaeration processes and concluded that DO supersaturation is not an adequate proxy for TDGS. Ma et al. (2013) compared the DO and TDG saturation concentrations, experimentally and in several aquatic ecosystems, and reached a similar conclusion. These authors base their conclusion on the significant differences between DO and TDG saturations in most aquatic bodies and on the absence of a clear and fixed relationship between them (Ma et al., 2013). However, their results also reveal that saturations of TDG and DO downstream of hydroelectric dams are linearly correlated, with variations in DO saturation explaining at least $80 \%$ of the variation in TDG saturation ( $\mathrm{R}^{2}$ statistic). Xue et al. (2019) also found a strong correlation between TDG and DO saturations downstream of the Xiangjiaba Dam in the Upper Yangtze River in $2014\left(\mathrm{R}^{2}=0.89\right)$, but not in $2015\left(\mathrm{R}^{2}=0.23\right)$. In 2015, however, the spillway discharge level (the main process associated with increased downstream gas saturation) was constant, and this likely stabilized the observed DO and TDG values, 
especially considering that TDG is already a relatively stable indicator (Ma et al., 2013). This reduced fluctuation in 2015 can also be seen in the DO saturation range, which was approximately $114 \%-124 \%$ in 2015 , against $109 \%-130 \%$ in 2014 , which may also have made it difficult to identify a stronger relationship between DO and TDG saturations in the last year.

A multi-parameter probe (Hydrolab brand, model MS5) capable of measuring DO and TDG saturations was installed in the deep layers of the outlet of a dam plunge channel, located on the Teles Pires River (Amazon basin, Brazil). Based on this probe, DO and TDG saturations were measured in two periods: from February 15, 2020 to April, 142020 and from November 1, 2020 to December 31, 2020. In the first period (Feb - Apr), frequent and intense spillway activities occurred, while in the second period (Nov - Dec), the spillway operation was less intense and more sporadic. However, it is possible - during both periods - to observe the relationship between DO and TDG saturations (Fig. 3). In the period of reduced and sporadic spillway activity, this relationship was less apparent, and TDG saturation exhibited minimal fluctuations and remained close to 100\%; nevertheless, DO saturation demonstrated significant fluctuations $(0-75 \%)$, although it remained always below 100\% (Fig. 3). During the period of intense spillway operation, variations in the saturation of TDG and DO were of the same order, but in different ranges of variations (112\% - 142\% for DO and 140\% - $170 \%$ for TDG). This result suggests that DO saturation is a better proxy for TDG when the spillway is working.

The relationship between TDG and DO saturation in the field study downstream of the dam is significant, with Spearman's correlation coefficient estimated at $0.92(\mathrm{p}<$ 0.001); however, this relationship is not necessarily linear (Fig. 4). The variability in DO saturation explains about $98 \%$ of the variability in TDG saturation, assuming quadratic, segmented, rectilinear relations with one and two breakpoints (Fig. 4). Although all models have a strong ability to identify levels of TDG supersaturation based on DO saturation levels, the most parsimonious model utilized segmented regression with two breakpoints. In this model, the line slope was lower in the first segment (slope $=0.13$, up to $71 \%$ DO), higher in the second segment (slope $=0.91$, for $71 \%<\mathrm{DO}<120 \%$ ), and intermediate in the last segment (slope $=0.54$, for DO $>120 \%$ ). These results show that for the evaluated site, the slope between TDG and DO is low in the absence of

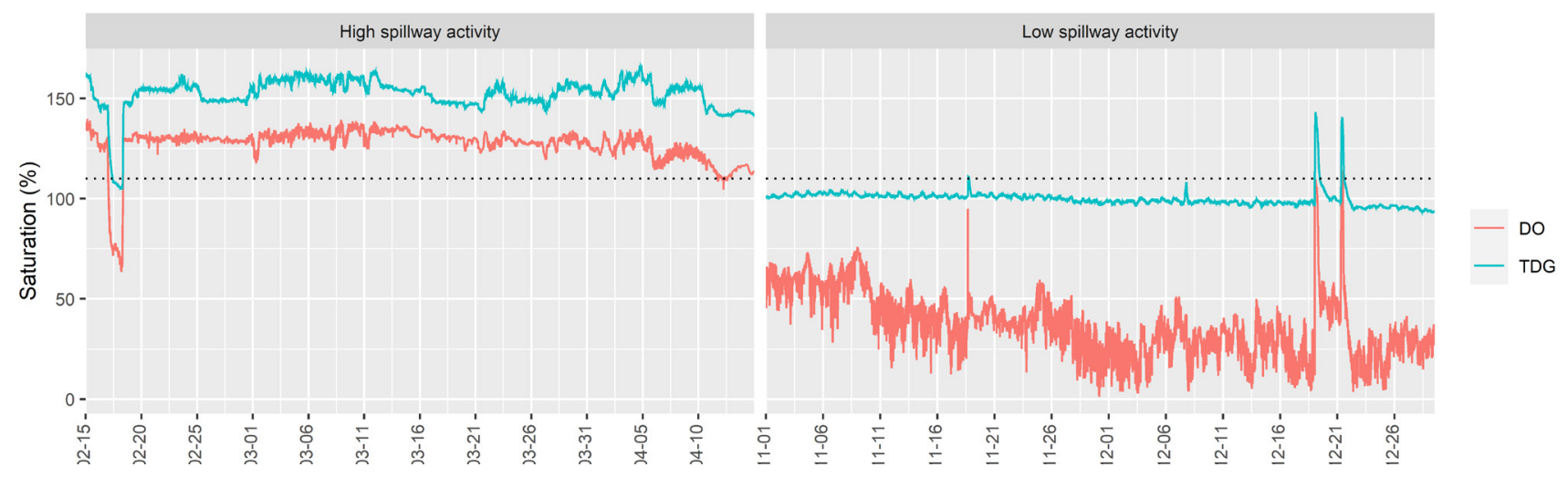

FIGURE 3 I Saturations of dissolved oxygen (DO, red) and total dissolved gases (TDG, blue), for periods with intense (left) and sporadic (right) dam spillway activities. The black dotted line indicates the threshold of $110 \%$ TDG saturation. 
supersaturation (pouring), as TDG saturation tends to remain stable around 100\%. Above $71 \%$ DO, the relationship becomes more accentuated, with the saturation of DO and TDG increasing via the same process - that of incorporating atmospheric air into the water through the spillway. Also, according to this same model, DO saturation levels of approximately $77 \%$ and $94 \%$ support the saturation thresholds of $110 \%$ (the maximum limit established by the EPA) and 125\% (the lethal limit, according to Fidler, Miller, 1994) of TDG. Therefore, it is possible to verify critical levels of gas supersaturation (TDG $>125 \%$ ) even without oxygen supersaturation (DO < 100\%).

These results indicate that oxygen supersaturation promoted by the spillway and measured just downstream of the plunge pool has an abiogenic origin, such as nitrogen and other gases that make up the TDG supersaturation (Harvey, Cooper, 1962; Weitkamp, Katz, 1980). Thus, it is possible to utilize DO saturation as a proxy to determine increments in TDG saturation when the processes involved have an abiogenic nature, as is the case of spillways and the dissolution of atmospheric gases. However, the correspondence between the critical thresholds at the DO and TDG levels is not generalizable and should, in most cases, be obtained in situ. This is because other factors, such as temperature and the reservoir water quality (Ma et al., 2013), can produce variations in the relationship between these two saturations across sites or even in time for the same location.

The characteristics of the sensors represent another factor complicating this relationship. In general, the response time of DO sensors is shorter than that of TDG sensors (Ma et al., 2013), and relevant differences between various TDG sensors can hinder the accuracy of cross-analyses (Tanner et al., 2003). It is possible to detect the

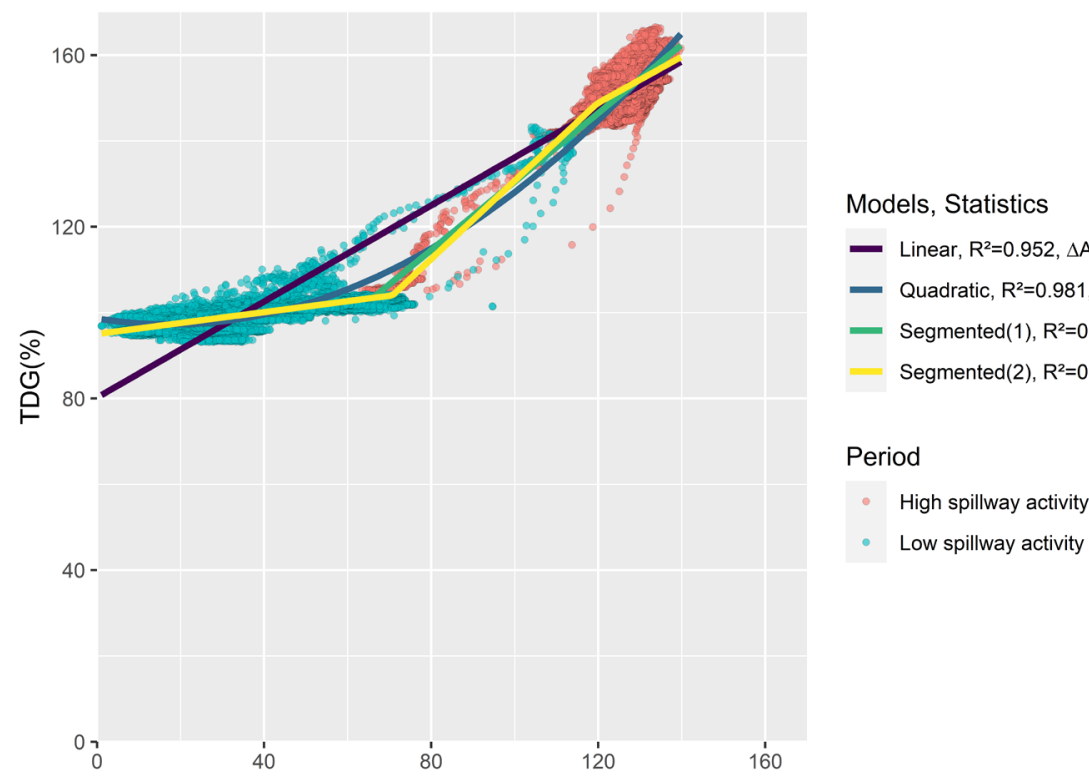

FIGURE 4 I TDG and DO saturations for periods with intense (red) and sporadic (blue) dam spillway activities. Four models were fitted to these data, all with TDG as a response and DO as a predictor. The models were: i) simple linear regression (Linear); ii) linear regression with quadratic effect of DO (Quadratic); iii) segmented linear regression, with 1 breakpoint and 2 segments (Segmented (1)); iv) segmented linear regression, with 2 breakpoints and 3 segments (Segmented (2)). The most parsimonious model with the lowest AIC was segmented regression (2). 
difference in the response time between the TDG and DO sensors through the loop effect obtained in the dispersion diagram of both variables. As Fig. 4 shows, the DO sensor was faster in response, mainly in the increase in saturation levels.

\section{DEATH EVENTS IN BRAZIL}

We evaluated freshwater fish mortality events in Brazilian hydrographic basins through a systematic Google search to identify news published about the subject (in open media) between 2010 and 2020. From the published news, we compiled the following information: date and place of the event, cause(s) attributed to the deaths, estimation of biomass affected, and species name (popular name). Aquatic environments were classified as dam/upstream, dam/downstream, fish farming, river, and urban lake. The causes of deaths were categorized into the following occurrences: accidental contamination, desiccation, hypoxia/anoxia, industrial sewage, mechanical shocks, TDS saturation, urban sewage, and unidentified cause. The amount of biomass lost was grouped into categories of $<100 \mathrm{~kg},<1$ ton, $>1$ ton, and "not estimated". A detailed description of the methodology is available in $\mathbf{S 1}$.

A total of 251 news stories about freshwater fish mortality were assessed (see Tab. S1). Fish mortality events were recorded in all Brazilian hydrographic basins, mainly in rivers and downstream of hydroelectric plants. There is a clear upward trend in the frequency of these events in recent years (Fig. 5A). There are no elements to identify the determinants of this trend. However, it seems likely that it was the result of the increasing facility of recording these events on videos and later sharing them on social media networks or even as complain to the television or newspapers. In fact, part of the news considered in this study was illustrated with material obtained from digital media. Events were more frequent in the Paraná and Amazon basins (Fig. 5B). The high degree of anthropization in the Paraná River basin (Agostinho et al., 2016) and the high biomass and fish species richness in the Amazon basin (Winemiller et al., 2016) may be reasons why fish die-off is more frequent in the first basin and have more dramatic repercussion in the last one.

Among the causes of mortality, most reported was hypoxia/anoxia (Tab. 1, Fig. 6A). Few of these cases of hypoxia/anoxia were attributed to natural causes. Rather, hypoxia/ anoxia resulted mainly from dam operations in hydroelectric plants, such as the opening or closing of emergency gate of the draft tube, especially those events described below dams (Fig. 6A). The greatest incidence occurred in the Paraná and Amazon basins. Hypoxia/anoxia is also associated to largest biomass losses of fishes (Fig. 6B). Only in these last-mentioned basins was fish mortality by desiccation recorded, and only in the Amazon basin it was attributed to TDS (Fig. 6B). Many causes of fish deaths were related to water pollution through the discharge of untreated urban, industrial, and mining sewage, especially in the Paraná basin (Fig. 6B).

In the Paraná basin, fish mortality caused by hypoxia/anoxia was also recorded in fish farms with cages. In addition to the Paraná basin, fish deaths in caged aquaculture systems were reported in reservoirs from other hydrographic basins, such as the Eastern Northeast Atlantic basin (see Barbosa, 2019) and the São Francisco River basin. In 2007, in the Xingó hydroelectric power plant reservoir, 297 tons of tilapia were lost. According to the report, gas embolism caused fish mortality, due to the sudden increase in river flow and gas supersaturation (Panorama da Aquicultura, 2007). 

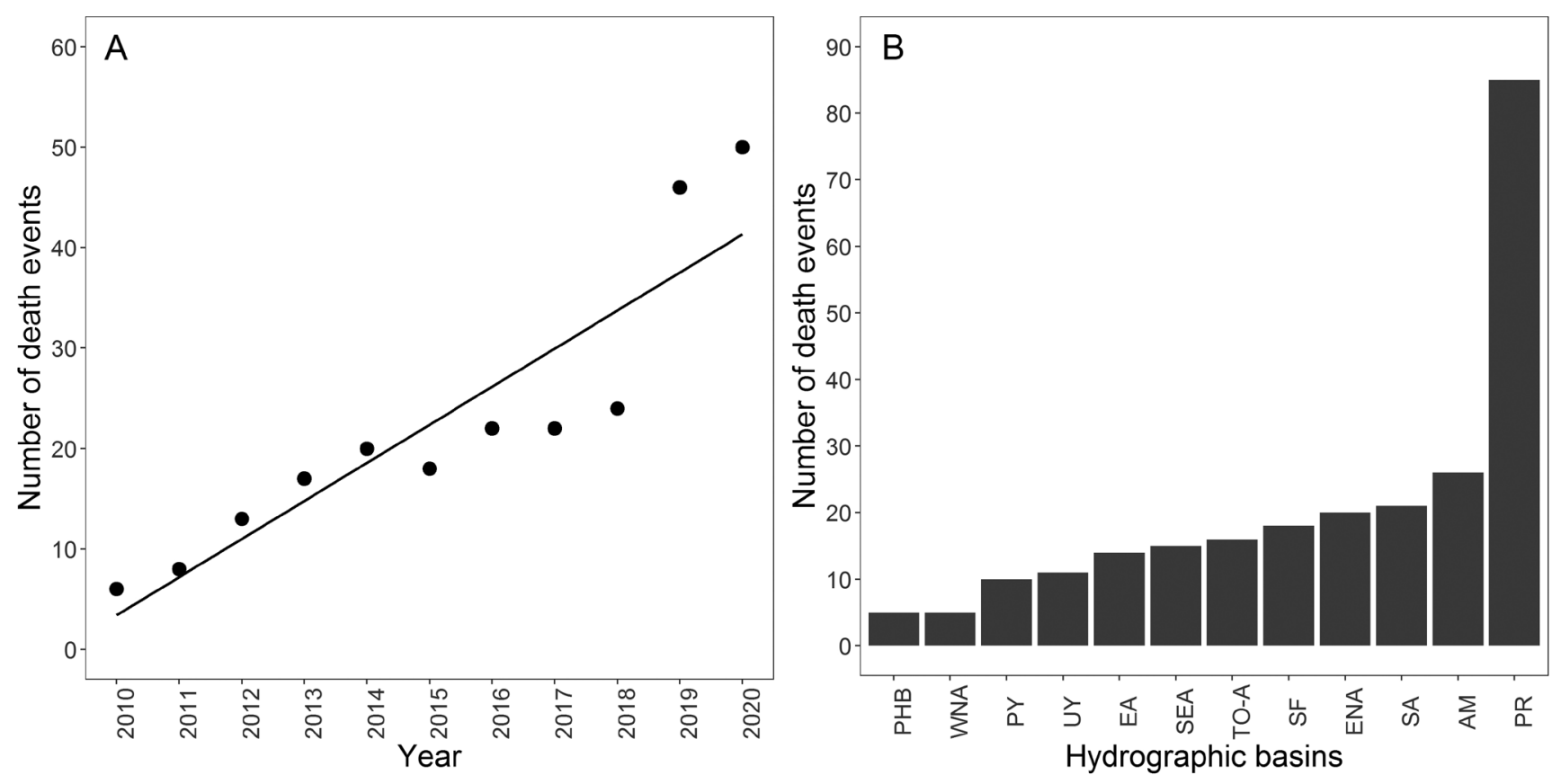

FIGURE 5 I Fish mortality events between 2010 and 2020 (A) and in different Brazilian hydrographic basins (B), as reported by news (Google searches). PHB = Parnaiba, WNA = Western Northeast Atlantic, PY = Paraguay, UY = Uruguay, EA = East Atlantic, SEA = Southeast Atlantic, TO-A = Tocantins-Araguaia Basin, SF = San Francisco, ENA = Eastern Northeast Atlantic, SA = Southeast Atlantic, AM = Amazon, PR = Paraná.

TABLE 1 I Frequency of fish mortality events recorded in Brazilian Hydrographic Basins, considering sites of death, causes, biomass affected and species, as reported by news (Google searches), between 2010 and 2020.

\begin{tabular}{|c|c|c|c|}
\hline Variable & Code & \multicolumn{2}{|c|}{ Frequency of death events } \\
\hline Site & & $\mathrm{n}$ & $\%$ \\
\hline Dam / Downstream & DDow & 59 & $24.0 \%$ \\
\hline Dam / Upstream & DUp & 4 & $1.6 \%$ \\
\hline Fish farming & FishF & 23 & $9.3 \%$ \\
\hline River & River & 133 & $54.1 \%$ \\
\hline Urban lake & UL & 27 & $11.0 \%$ \\
\hline \multicolumn{4}{|l|}{ Cause } \\
\hline Accidental contamination & $\mathrm{AC}$ & 18 & $7.3 \%$ \\
\hline Desiccation & $\mathrm{DE}$ & 2 & $0.8 \%$ \\
\hline Hypoxia / anoxia & HA & 99 & $40.2 \%$ \\
\hline Industrial sewage & IS & 43 & $17.5 \%$ \\
\hline Mechanical shocks & MS & 1 & $0.4 \%$ \\
\hline TDS saturation & TDS & 2 & $0.8 \%$ \\
\hline Urban sewage & US & 48 & $19.5 \%$ \\
\hline Unknown & Uk & 33 & $13.4 \%$ \\
\hline \multicolumn{4}{|l|}{ Magnitude } \\
\hline$<100 \mathrm{~kg}$ & & 17 & $6.9 \%$ \\
\hline$<1$ ton & & 31 & $12.6 \%$ \\
\hline$>1$ ton & & 77 & $31.3 \%$ \\
\hline Not estimated & & 121 & $49.2 \%$ \\
\hline \multicolumn{4}{|l|}{ Species } \\
\hline not identified & & 16 & $6.5 \%$ \\
\hline unique & & 35 & $14.2 \%$ \\
\hline various & & 195 & $79.3 \%$ \\
\hline
\end{tabular}



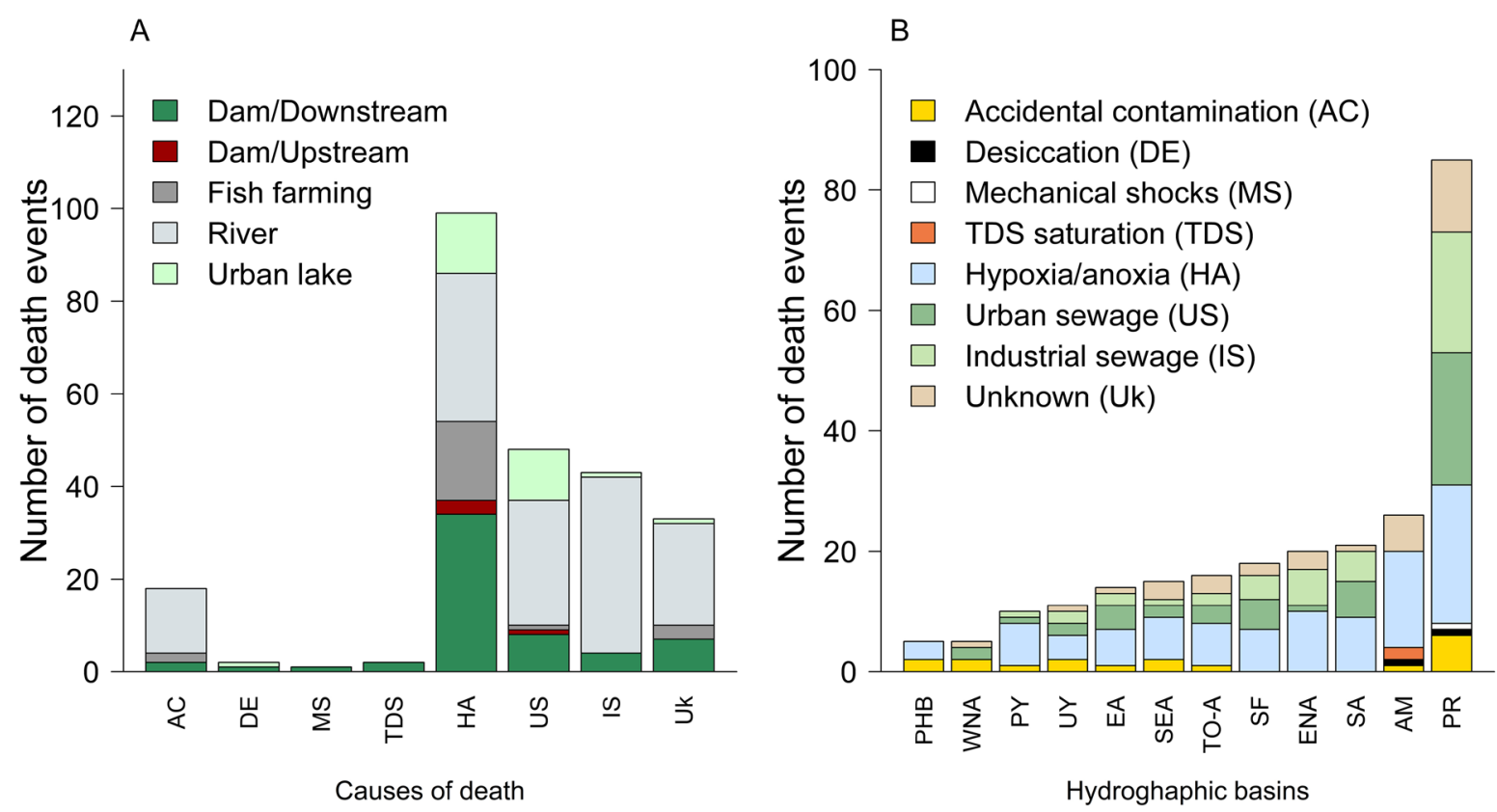

FIGURE 6 I (A) Number of fish mortality events at different sites, considering the cause of death and (B) Number of fish mortality events at different sites, by cause of death attributed considering the Brazilian hydrographic basins. PHB $=$ Parnaiba, WNA = Western Northeast Atlantic, PY = Paraguay, UY = Uruguay, EA = East Atlantic, SEA = Southeast Atlantic, TO-A = Tocantins-Araguaia Basin, $\mathrm{SF}=\mathrm{San}$ Francisco, ENA = Eastern Northeast Atlantic, SA = Southeast Atlantic, AM = Amazon, PR = Paraná. See codes for causes of death in Tab. 1.

Hydropower is especially related to fish death during the reservoir filling or the turbines or floodgates commissioning, before commercial operation. Activities like the opening/closing of floodgates and the starting and stopping turbines are directly related to water level in the reservoir and in the downstream section of the river. As mentioned, during reservoir filling, the decomposition of organic matter can reduce dissolved oxygen concentration (see G1 MT, 2019), in addition to increasing turbidity, due to the mobilization of deposit accumulated during the dam construction (Faerman, 2019). Regarding the cause of the event reported in these two news: anoxia (see G1 MT, 2019) and branchial obstruction by sediments (Faerman, 2019), further investigations revealed that the information sources of both were partially mistaken, considering that gas supersaturation was the main cause of death.

High fish mortality has been associated with the closure of floodgates, which generally occurs in the dry season when the reservoir suffers a reduction in the water level that requires a shutdown of the generating units. Sudden changes in dam operations affect the amount of water downstream, which may cause the deaths of tons of fish below the dam (see G1 TO, 2014). These fish mortality events are especially likely when fish remain trapped in pools, usually under anoxic conditions. Sudden changes in operation (stopping and starting) can also cause high mortality when fish are attracted by temporarily low water velocity, entering inside the draft tube, and dying due to insufficient oxygen or shock with the components of the turbines (see IBAMA, 2018). The opening of the floodgates-to release water from the reservoir and regulate river flow or to facilitate turbine operation and remove aquatic plants, for example - is the main 
activity related to fish mortality events. In this context, the release of water may lead to gas supersaturation (see G1 AP, 2015). The opening of the floodgates, with the release of water from the reservoir to regulate river flow or turbine operation (including the removal of aquatic plants, for example), are the main activities related to death events. In this context, the release of water may lead to gas supersaturation (see G1 AP, 2015).

Several fish species are affected by mortality events (Tab. 1) that result from water pollution or hydroelectric power plant operations. However, the species that attract the most attention from the media and fishers are those of large size and significant commercial interest (such as matrinchã, curimba, cachara, pacu, pintado, dourado, jaú, jurupoca, piraputanga). In relation to the dams, fishers express concern regarding the procedures and timing of dam operations, as many operations occur abruptly or during critical periods, such as spawning season. It is worth mentioning that most media reports did not identify the species involved (popular name) and they did not quantify biomass loss (Tab. 1), indicating underestimation of the number of dead fish. Sometimes, pressured by demands for clarification from society, the person responsible for the fish die-off assessment discloses wrong conclusions about the cause of death, promptly released by the media. This is more common below dams, where identification is complex and necropsies are often performed when the lethality factor is already gone. In fact, some events considered in this compilation were preliminarily attributed to anoxia or high turbidity and so published, being later reclassified as total dissolved gases supersaturation and barotrauma (AAA, pers. data).

\section{PREVENTION AND MITIGATION}

Hipoxia and anoxia. Natural events that may affect the concentration of dissolved oxygen, especially those related to excessive rains, long droughts, and eutrophication of aquatic systems, are predictable, but their prevention or mitigation is difficult because their occurrence is diffuse. The greater climatic instability resulting from global climate changes and the consequent increase in the processes of mineralization, increase in the biomass of cyanophycean algae, increase in organic matter in the sediment, greater turbidity, and increased water heating (Moss et al., 2011; Morsy et al., 2017) may result in processes of hypoxia or anoxia, which are aggravated by the increased water temperature. Therefore, actions that aim to reduce global warming and avoid the excess of nutrients in water systems are needed. Every citizen has a role in these initiatives, but for the initiatives to be effective, they must be coordinated by governments.

The development of anoxic layers in reservoirs impedes the use of their water for multiple purposes and the survival of aquatic biota inhabiting them. Environmental control agencies sometimes demand the wholescale removal of vegetation from areas to be flooded by a reservoir. As a preventive measure to avoid anoxia, however, this does not seem to be the best option for the conservation of the fish fauna. In fact, the major problems related to anoxia in reservoirs are those related to the biomass of labile organic matter (e.g., litter, herbaceous plants, grasses, and regrowth of the removed vegetation), and these are, generally, difficult to control.

In contrast, woody material, whose decomposition may take more than a century, represents a low risk to acute problems of hypoxia or anoxia (Agostinho et al., 2007). Moreover, this material is valuable as an underwater structure, providing shelter for fish, 
substrate for some items of their diet (periphyton and associated fauna), and locations for spawning (Ploskey, 1985; Gois et al., 2012). The prevention of hypoxia or anoxia is possible via mathematical models and simulations of water quality under distinct scenarios of vegetation removal.

Water level variations upstream and downstream may constitute chronic problems in hydroelectric power plants when pools are formed and shoals are retained, especially downstream (Rêgo et al., 2016). This is particularly true for dams that operate under the accumulation scheme. Slower maneuvers that allow fish to escape the area before the water level decreases may offer one solution. When possible, the construction of drainage canals that contribute pools to the main water body, in addition to the regularization of the topography, are likewise needed (Loures et al., 2016b). However, if the problem persists, manual rescues are essential during any maneuver that potentially causes relevant alterations in the water level.

Fish deaths by hypoxia or anoxia inside turbines are common in Neotropical dams. Their mitigation depends on the availability and ability of infrastructure and equipment to identify the current conditions inside the turbines (oxygen and fish biomass) and to aerate their compartments (suction tube, spiral case, draft tube), as well as those to rescue retained fish. Thus, the design of dams must incorporate these facilities. In particular, the velocity at which retained fish inside a turbine are removed is considered a critical factor for fish survival (Loures et al., 2016b). Information about seasonal variations in the abundance of fish downstream of dams and the adjustment of the agenda for the maintenance of the turbines as well as the incorporation of this information into the decision-making process is recognized as other ways of mitigation. In addition, barriers that have been considered as a way to reduce or block the entrance of fish into the turbines from the tailrace (Agostinho et al., 2007; Loures et al., 2016b). Electricity, sound, bubbles, and lights, as well as metal screens, are barriers that have been considered as a way to reduce or block the entrance of fish into the turbines from the tailrace (Agostinho et al., 2007; Andrade et al., 2012; Loures et al., 2016b).

TDG supersaturation. The most recommended strategy to avoid problems with gas supersaturation in the water downstream dams must be considered during the design phase of the dam project. This stage defines ways to dissipate the energy of the water released by the spillway, including the water outflow design, the design of deflector and diversion structures, and the elevation and form of the dissipation basin and secondary water outlet of the dam. Measures of the duration, intensity, and extension of gas supersaturation are mainly determined by the flow rate and depth to which the released water may sink in the dissipation basin; depending on various factors, these measures may reach very high and lethal values (Fidler, Miller, 1994).

After the construction of the dam, water released from the spillway may promote periodic or permanent gas supersaturation events; in fact, these events are inevitable when the dam is operating. These events, in turn, will demand the application of methods and procedures to protect the biota from critical levels of supersaturation. Available methods focus on the reduction of supersaturated waters, the increase in the dissipation rate (Politano et al., 2009; Tang, 2011), and improvements or amplification of areas for refuge with decreased levels of saturation (Shen et al., 2016). The use of deflectors may reduce the levels of saturation by redirecting the flow from the spillway, making it 
flatter in relation to the water surface, and preventing the air bubbles from penetrating deep into the dissipation bay (Politano et al., 2009). Sky-jump is the spillway design considered the best to dissipate energy and avoid supersaturation (Feng et al., 2018).

In some cases, however, the manipulation of habitat to provide areas for refuge and shelter is the only available solution in the short and medium term. Such areas will be available downstream dams when waters less saturated with gases, including oxygen, flow from the turbines or from tributaries that empty in the vicinity. In addition, refuge areas may be present in the deeper layers of the water column where depth allows. In this last case, as already mentioned, even if the entire water column has the same concentration of TDG, it may be supersaturated only on the surface since supersaturation is related to hydrostatic pressure. Engineering solutions, such as the excavation of the riverbed and the construction of obstacles below the restitution flow canal or in the vicinity of the mouth of tributaries, may further increase refuge and shelter areas (Shen et al., 2016; Shen et al., 2019). The presence of submerged vegetation during high water flows may also contribute to the dissipation of gas supersaturation (Yuan et al., 2018).

To mitigate the impacts of supersaturation and improve shelter areas, the operational optimum must be determined in relation to the generation of hydroelectricity. To achieve this, planners must identify and characterize areas for shelter in different scenarios of turbine and spillway operation, always considering the latter as the producer of gas supersaturation and the former as the producer of areas for shelter (Wan et al., 2020). However, these efforts require further efforts to register and save continuous data on TDG saturation and the operation of spillway and turbines. All power plants that have the potential to generate gas supersaturation should utilize equipment to measure TGP at the end of the dissipation canal. Alternatively, government regulation could make this mandatory during the process of environmental licensing. Besides ongoing monitoring of their supersaturation levels, power plants with a history of fish mortality events downstream the dam should extend this monitoring even further downstream. A sampling design including saturometers in several sites downstream, such as the restitution canal, dissipation canal, and further downstream the dam (to the center and margins of the wet area), can instruct the operation of the hydraulic structures (turbines and spillway) with the data from TDG supersaturation. These saturometers should gather information from the surface and near the bottom as well. With adequate information, it may be possible to propose operational procedures that minimize the damage to fish from gas supersaturation.

\section{FINAL REMARKS}

Although recorded on unregulated rivers, fish mortality events are most often downstream from dams. Therefore, these events tend to increase with the expansion of hydroelectric dams throughout the all-large hydrographic basins of South America. This review can be considered the basis for the initial understanding of these events including their origins, consequences, and forms of prevention and mitigation of fish deaths below dams. It is also presented the complexity around the theme and supplied some guidelines to be considered to minimize their effects. The processes linked to deaths due to anoxia in Neotropical environments are well studied, with several papers on the subject. However, for gas supersaturation, we are just beginning. In fact, we 
have not recognized it completely in events of fish deaths. The first scientific paper on gas supersaturation was published recently (Gama, 2020), and basically reported that it occurred. A detailed understanding of this theme, through research and monitoring, should be considered a priority, once the deaths of fish represent: (i) ecosystem losses (biodiversity, functions, and services), (ii) socioeconomic and food security losses (fishery and landed fish), and (iii) image wear and financial losses for the energy companies, which even not having the control and the understanding on how to avoid these accidents, are responsible for their consequences. In addition to the relevance of the studies, it appears from what was presented that environmental control agencies should contemplate, in the term of reference in the hydropower license process the evaluation of the environmental impacts related to the operation of the hydraulic structures (spillway and turbines). This should consider the design of the spillway, characteristics of the energy dissipation basin, in addition to facilities for aeration and access to the compartments of the turbines. During the hydraulic structures commissioning, when these are tested to ensure that they have been properly designed, manufactured, installed, and operated, it is a great opportunity to assess whether their physical and operational characteristics are friendly to fish fauna.

\section{ACKNOWLEDGMENTS}

The authors are grateful to $\mathrm{CNPq}$ for its continued support to AAA and FMP (PQ scholarship) and RMD (post-doc scholarship).

\section{REFERENCES}

- Abernethy CS, Amidan BG, Cada GF. Laboratory studies of the effects of pressure and dissolved gas supersaturation on turbine-passed fish. Falls, Idaho: U.S. Department of Energy, Idaho Operation Office; 2001; 1-61. https://doi. org/10.2172/782074

- Agostinho AA, Gomes LC, Pelicice FM. Ecologia e manejo de recursos pesqueiros em reservatórios do Brasil. Maringá: EDUEM; 2007.

- Agostinho AA, Gomes LC, Santos NCL, Ortega JCG, Pelicice FM. Fish assemblages in Neotropical reservoirs: colonization patterns, impacts and management. Fish Res. 2016; 173(part 1):26-36. http://dx.doi. org/10.1016/j.fishres.2015.04.006

- Algera DA, Rytwinski T, Taylor JJ, Bennett JR, Smokorowski KE, Harrison PM et al. What are the relative risks of mortality and injury for fish during downstream passage at hydroelectric dams in temperate regions? A systematic review. Environ Evid. 2020; 9(3):1-36. https://doi. org/10.1186/s13750-020-0184-0
- Andrade F, Prado IG, Loures RC, Godinho AL. Evaluation of techniques used to protect tailrace fishes during turbine maneuvers at Três Marias Dam, Brazil. Neotrop Ichthyol. 2012; 10(4):723-30. https://doi.org/10.1590/S167962252012000400005

- Bacchiega JD, Fattor CA. Yacyretá Dam: spillways modification to reduce total dissolved gases concentrations downstream of the dam. In: Yazdandoost F, Attari J, editors. Hydraulics of Dams and River Structures: Proceedings of the International Conference, Tehran, Iran, 26-28. London: A. A. Balkema publishers; 2004. p.104-17.

- Baird IG, Flaherty MS, Phylavanh B. Preliminary evidence of gas supersaturation below the Mekong River's Khone Falls in Southern Laos PDR. In: Environmental Protection and Community Development in Siphandone Wetland project. Pakse: CESVI; 1999. 14p. 
- Barbosa H. Nova mortandade de peixes encerra a piscicultura no Castanhão [Internet]. Fortaleza: Diário do Nordeste; 2019. Available from: https://diariodonordeste.verdesmares. com.br/regiao/nova-mortandadede-peixes-encerra-a-piscicultura-nocastanhao-1.2102361

- Bianchini I Jr., Toledo APP. Estudo da mineralização de Nymphoides indica. Anais do VII Seminário Regional de Ecologia. 1998; 3:1315-29.

- Bouck GR. Etiology of gas bubble disease. Trans Am Fish Soc. 1980; 109(6):703-07.

- Boyd CE, Watten BJ, Goubier V, Wu R. Gas supersaturation in surface waters of aquaculture ponds. Aquac Eng. 1994; 13(1):31-39. https://doi.org/10.1016/01448609(94)90023-X

- Bragg HM, Johnston MW. Total dissolved gas and water temperature in the lower Columbia River, Oregon and Washington, water year 2015 [Internet]. Oregon: U.S. Geological Survey; 2016. Available: http:// dx.doi.org/10.3133/ofr20151212

- Brauner CJ, Ballantyne CL, Randall DJ, Val AL. Air breathing in the armoured catfish (Hoplosternum littorale) as an adaptation to hypoxic, acid, and hydrogen sulphide rich waters. Can J Zool. 1995; 73(4):739-44. https://doi.org/10.1139/z95086

- Cada GF, Coutant CC, Whitney RR. Development of biological criteria for the design of advanced hydropower turbines [Internet]. Idaho Falls; 1997. Available from: https://doi.org/10.2172/1218126

- Calheiros DF, Seidl AF, Ferreira CJA. Participatory research methods in environmental science: local and scientific knowledge of a limnological phenomenon in the Pantanal wetland of Brazil. J Appl Ecol. 2000; 37(4):684-96. https://doi. org/10.1046/j.1365-2664.2000.00524.x

- Cao C, Deng Y, Yin Q, Li N, Liu X, Shi $\mathrm{H}$ et al. Effects of continuous acute and intermittent exposure on the tolerance of juvenile yellow catfish (Pelteobagrus fulvidraco) in total dissolved gas supersaturated water. Ecotoxicol Environ Saf. 2020; 201(110855):1-09. https://doi. org/10.1016/j.ecoenv.2020.110855
- Cao L, Li Y, An R, Wang Y, Li K, Buchmann K. Effects of water depth on GBD associated with total dissolved gas supersaturation in Chinese sucker (Myxocyprinus asiaticus) in upper Yangtze River. Sci Rep. 2019; 9(6828):1-08. https:// doi.org/10.1038/s41598-019-42971-8

- Cao L, Li K, Liang R, Chen S, Jiang W, Li R. The tolerance threshold of Chinese sucker to total dissolved gas supersaturation. Aquac Res. 2016; 47(9):2804-13. https://doi.org/10.1111/ are.12730

- Chen SC, Liu XQ, Jiang W, Li KF, Du J, Shen DZ, Gong Q. Effects of total dissolved gas supersaturated water on lethality and catalase activity of Chinese sucker (Myxocyprinus asiaticus Bleeker). J Zhejiang Univ Sci B. 2012; 13(10):791-96. https://doi.org/10.1631/jzus.B1200022

- Chen YB, Peng QD, Liao WG. The evolvement study on supersaturation of dissolved gas in the middle reaches of Yangtze River after the Three Gorges project running. J Hydroecol. 2009; 2(5):105.

- Chesney EJ, Baltz DM, Thomas RG. Louisiana estuarine and coastal fisheries and habitats: perspectives from a fish's eye view. Ecol Appl. 2000; 10(2):350-66. https://doi.org/10.1890/10510761(2000)010[0350:LEACFA]2.0.CO;2

- Cunha-Santino MB, Bianchini I Jr., Serrano LEF. Aerobic and anaerobic degradation of tannic acid on water samples from Monjolinho reservoir (São Paulo, SP, Brazil). Braz J Biol. 2002; 62(4a):585-90. https://doi.org/10.1590/ S1519-69842002000400004

- Cunico AM, da Graça WJ, Verissimo S, Bini LM. Influence of the hydrological level on an assemblage of fishes at a seasonally isolated lagoon of the Upper Paraná River floodplain. Acta Sci. 2002; 24(2):383-89.

- Deng Y, Cao C, Liu X, Yuan Q, Feng C, Shi H et al. Effect of total dissolved gas supersaturation on the survival of bighead carp (Hypophthalmichthys nobilis). Animals. 2020; 10(166):1-14. https://doi. org/10.3390/ani10010166

- Diaz RJ. Overview of hypoxia around the world. J Environ Qual. 2001; 30(2):275-81. https://doi.org/10.2134/jeq2001.302275x 
- Dickson KA, Graham JB. Adaptations to hypoxic environments in the erythrinid fish Hoplias microlepis. Environ Biol Fish. 1986; 15(4):301-08.

- Domitrovic HA, Bechara JA, Flores Quintana C, Roux JP, Gavilán G. A survey study of gas supersaturation and fish gas bubble disease in the Paraná River below Yacyretá Dam, Argentina. Rev Ictiol. 2000; 8(1/2):29-40.

- Domitrovic HA, Bechara JA, Jacobo WR, Flores Quintana C, Roux JP. Mortandad de peces en el río Paraná provocada por sobresaturación de gases: causas y lesiones. Rev Ictiol. 1994; 2/3(1/2):49-54.

- Esteves FA. Fundamentos de limnologia. Rio de Janeiro: Interciência; 1998.

- Faerman H. UHE Sinop é multada em R\$ 50 milhões por poluição e morte de peixes [Internet]. Canal Energia; 2019. Available from: https://www. canalenergia.com.br/ noticias/53090355/ uhe-sinop-e-multadaem-r-50-milhoes-por- poluicao-e-morte-depeixes

- Fan Z, Deng Y, Yuan Q, Liu X, Shi H, Feng C, Yang Y, Xu L. Effect of total dissolved gas supersaturation on the tolerance of grass carp (Ctenopharyngodon idellus). Environ Sc Eur. 2020; 32(55):1-10. https:// doi.org/10.1186/s12302-020-00330-9

- Feng C, Li N, Wang Y, Liu X, Shi X, Fu C et al. Effects of total dissolved gas supersaturated water at varying suspended sediment concentrations on the survival of rock carp Procypris rabaudi. Fish Sc. 2019; 85(6):1067-75. https://doi. org/10.1007/s12562-019-01344-w

- Feng J, Wang L, Li R, Li K, Pu X, Li Y. Operational regulation of a hydropower cascade based on the mitigation of the total dissolved gas supersaturation. Ecol Indic. 2018; 92:124-32. https://doi.org/10.1016/j. ecolind.2017.04.015

- Feng JJ, Li R, Li K F, Li J, Qu L. Study on release process of supersaturated total dissolved gas downstream of high dam. J Hydroelec Eng. 2010; 29:7-12.

- Fernández-Osuna MA, Scarabotti PA. Phenotypic plasticity associated to environmental hypoxia in the neotropical serrasalmid Piaractus mesopotamicus (Holmberg, 1887) (Characiformes: Serrasalmidae). Neotrop Ichthyol. 2016; 14(2):e150187. https://doi.org/10.1590/1982 0224-20150187
- Fidler LE, Miller SB. Britsh Columbia water quality guidelines for dissolved gas supersaturation. Canada: BC Ministry of Environment Canada Department of Fisheries and Oceans Environment; 1994. Available from: https://www2.gov. bc.ca/assets/gov/environment/air-landwater/water/waterquality/water-qualityguidelines/approved-wqgs/totalgas-tech.pdf

- G1 AP. Hidrelétrica pode ter causado morte de peixes no rio Araguari, diz polícia [Internet]. Macapá: G1 Amapá AP: notícias e vídeos da Rede Amazônica; 2015. Available from: http://g1.globo.com/ ap/amapa/noticia/2015/11/hidreletricapode-ter-causado-morte-de-peixes-no-rioaraguari-diz-policia.html

- G1 MT. Cerca de 13 toneladas de peixes morrem em água poluída entre dois reservatórios de usina no Rio Teles Pires em MT [Internet]. Cuiabá: G1, Mato Grosso - MT: notícias e vídeos da TV Centro América; 2019. Available from: https:/g1.globo.com/mt/mato-grosso/ noticia/2019/02/11/cerca-de-13-toneladasde-peixes-morrem-em-agua-poluida-entredois-reservatorios-de-usina-no-rio-telespires-em-mt.ghtml

- G1 T0. Milhares de peixes são encontrados mortos próximo à usina no Tocantins [Internet]. Pamas: G1 Tocantins - TO: notícias e vídeos de TV Anhanguera ; 2014. Available: http://g1.globo.com/to/tocantins/ noticia/2014/02/milhares-de-peixes-saoencontrados-mortos-proximo-usina-notocantins.html

- Gama CS. Estudo acerca da mortandade de peixes no AHE Ferreira Gomes, rio Araguari, Ferreira Gomes, AP. Arquivos Científicos (IMMES). 2020; 3(2):129-36. https://doi.org/10.5935/2595-4407/rac. immes.v3n2p129-136

- Godinho AL, Loures RC. Risco de morte de peixes em usinas hidrelétricas. In: Loures RC, Godinho AL. Avaliação de risco de morte de peixes em usinas hidrelétricas. Belo Horizonte: Companhia Energética de Minas Gerais; 2016. p.19-35.

- Gois KS, Antonio RR, Gomes LC, Pelicice FM, Agostinho AA. The role of submerged trees in structuring fish assemblages in reservoirs: two case studies in South America. Hydrobiologia. 2012; 685:109-19. https://doi.org/10.1007/s10750-011-0843-9

- Gorham FP. The gas-bubble disease of fish and its cause. Bull US Fish Comm for 1899.1900; 19:33-37. 
- Harvey HH, Cooper AC. Origin and treatment of a supersaturated river water. IPSFC Prog Rep. 1962; 9(7):1-09.

- Heccbercet TG. Effect of supersaturated water on fish in the River Nidelva, southern Norway. J Fish Biol. 1984; 24(1):65-74. https://doi. org/10.1111/j.1095-8649.1984.tb04777.x

- Hibbs DE, Gulliver JS. Prediction of effective saturation concentration at spillway plunge pools. J Hydraul Eng. 1997; 123(11):940-49. https://doi.org/10.1061/ (ASCE)0733-9429(1997)123:11(940)

- Huang X, Li KF, Li R, Li J, Du J. Experimental system for the simulation of total dissolved gas supersaturated water of high dams. J Sichuan Univ Eng Sci Ed. 2010; 42(4):25-28.

- IBAMA pede autorização de turbinas de Belo Monte por morte de peixes [Internet]. São Paulo: Ecycle; 2018. Available from: https://www.ecycle.com.br/ ibama-paralisacao-belo-monte-por-mortede-peixes

- Ji Q, Xue S, Yuan Q, Yuan Y, Wang Y, Liang $\mathbf{R}$ et al. The tolerance characteristics of resident fish in the upper Yangtze River under varying gas supersaturation. Int J Environ Res Public Health. 2019; 16(11):113. https://doi.org/10.3390/ijerph16112021

- Kramer DL, Lindsey CC, Moodie GEE, Stevens ED. The fishes and the aquatic environment of the central Amazon basin, with particular reference to respiratory patterns. Can J Zool. 1978; 56(4):717-29. https://doi.org/10.1139/z78-101

- Kramer DL. Dissolved oxygen and fish behavior. Environ Biol Fishes. 1987; 18:8192. https://doi.org/10.1007/BF00002597

- Li R, Hodges BR, Feng J, Yong X. Comparison of supersaturated total dissolved gas dissipation with dissolved oxygen dissipation and reaeration. J Environ Eng. 2013; 139(3):385-90. https://doi.org/10.1061/(ASCE)EE.19437870.0000598

- Li R, Li J, Li KF, Deng Y, Feng JJ. Prediction for supersaturated total dissolved gas in high-dam hydropower projects. Sci China Ser E-Technol Sci. 2009; 52(12):3661-67. https://doi.org/10.1007/ s11431-009-0337-4
- Liu X, Li N, Feng C, Fu C, Gong Q, Lai J et al. Lethal effect of total dissolved gassupersaturated water with suspended sediment on river sturgeon (Acipenser dabryanus). Sci Rep. 2019; 9(13373):1-6. https://doi.org/10.1038/s41598-019-49800-y

- Loures RC, Godinho AL, Silva RJ, Andrade F, Rego ACL, Carvalho MM et al. Metodologia para avaliação de risco de morte de peixes em usinas hidrelétricas. In: Loures RC, Godinho AL. Avaliação de risco de morte de peixes em usinas hidrelétricas. Belo Horizonte: Companhia Energética de Minas Gerais; 2016a. p.3770.

- Loures RC, Godinho AL. Avaliação de risco de morte de peixes em usinas hidrelétricas. Belo Horizonte: Companhia Energética de Minas Gerais; 2016.

- Loures RC, Schmidt NJP, Silva RJ, Joncew I, Dias JS, Pontelo EGG. Recomendações para proteção de peixes em novos empreendimentos hidrelétricos. In: Loures RC, Godinho AL. Avaliação de risco de morte de peixes em usinas hidrelétricas. Belo Horizonte: Companhia Energética de Minas Gerais; 2016b. p.273-95.

- Lowe-McConnell RH. Ecological studies in tropical fish communities. Cambridge: Cambridge University Press; 1986.

- Lu J, Li R, Ma Q, Feng J, Xu W, Zhang F, Tian Z. Model for total dissolved gas supersaturation from plunging jets in high dams. J Hydraul Eng. 2019; 145(1):04018082. https://doi.org/10.1061/ (ASCE)HY.1943-7900.0001550

- Lund M, Heggberget TG. Avoidance response of two-year old rainbow trout, Salmo gairdneri Richardson, to air-supersaturated water: Hydrostatic compensation. J Fish Biol. 1985; 26(2):193-200. https://doi. org/10.1111/j.1095-8649.1985.tb04256.x

- Ma Q, Li R, Feng J, Wang L. Relationships between total dissolved gas and dissolved oxygen in water. Fresenius Environ Bull. 2013; 22(11):3243-250.

- Matthews WJ. Patterns in freshwater fish ecology. Norman: Kluwer Academic Publishers; 2003.

- Miranda LE, Driscoll MP, Allen MS. Transient physicochemical microhabitats facilitate fish survival in inhospitable aquatic plant stands. Freshw Biol. 2000; 44(4):617-28. https://doi.org/10.1046/j.13652427.2000.00606.x 
- Morsy K, Morsy A, Morsy M, Thakeb H. Eutrophication of aquatic ecosystems: A viewpoint on the environmental impact of climate change. J Environ Sci Eng. 2017; 6:506-14. http://doi.org/10.17265/21625263/2017.10.002

- Moss B, Kosten S, Meerhoff M, Battarbee RW, Jeppesen E, Mazzeo N et al. Allied attack: climate change and eutrophication. Inland Waters. 2011; 1(2):101-05. https:// doi.org/10.5268/IW-1.2.359

- Panorama da Aquicultura. Piscicultores do São Francisco amargam novo prejuízo com mortalidades de tilápias [Internet]. Panorama da Aquicultura. 2007; 99:65. Available from: https:// panoramadaaquicultura.com.br/ piscicultores-do-sao-francisco-amargamnovo-prejuizo-com-mortalidades-detilapias/

- Pelicice FM, Agostinho AA, Thomaz SM. Fish assemblages associated with Egeria in a tropical reservoir: investigating the effects of plant biomass and diel period. Acta Oecol. 2005; 27(1):9-16. https://doi. org/10.1016/j.actao.2004.08.004

- Petry AC, Abujanra F, Gomes LC, Júlio HF, Jr., Agostinho AA. Effects of the interannual variations in the flood pulse mediated by hypoxia tolerance: the case of the fish assemblages in the Upper Paraná River floodplain. Neotrop Ichthyol. 2013; 11(2):413-24. https://doi.org/10.1590/S167962252013005000008

- Pleizier NK, Algera D, Cooke SJ, Brauner CJ. A meta-analysis of gas bubble trauma in fish. Fish Fish. 2020; 21(6):1175-94. https://doi.org/10.1111/faf.12496

- Ploskey GR. Impacts of terrestrial vegetation and preimpoundment clearing on reservoir ecology and fisheries in the USA and Canadá. FAO Fisheries Technological Papers. 1985; 285. 35p.

- Politano M, Carrica P, Weber L. A multiphase model for the hydrodynamics and total 470 dissolved gas in tailraces. Int J Multiphase Flow. 2009; 35(11):1036-050.

- Pollock MS, Clarke LMJ, Dubé MG. The effects of hypoxia on fishes: from ecological relevance to physiological effects. Environ Rev. 2007; 15:1-14. https:// doi.org/10.1139/a06-006

- Pompeu PS, Godinho, HP. Effects of extended absence of flooding on the fish assemblages of three floodplain lagoons in the middle São Francisco River, Brazil. Neotrop Ichthyol. 2006; 4(4):427-33. https:// doi.org/10.1590/S1679-62252006000400006
- Prado IG, Pompeu PS. Diel vertical migration of fish in a Neotropical reservoir.Mar Freshw Res.

2017;68(6):1070-78. https://doi.org/10.1071/ MF16009

- Rahel FJ, Nutzman JW. Foraging in a lethal environment-fish predation in hypoxic waters of a stratified lake. Ecology. 1994; 75(5):1246-53. https://doi. org/10.2307/1937450

- Rantin FT, Johansen K. Responses of the teleost Hoplias malabaricus to hypoxia. Env Biol Fish. 1984; 11:221-28. https://doi. org/10.1007/BF00000466

- Rêgo ACL, Prado IG, Silva TT, Loures RC, Silva RJ, Monteiro AB, Godinho AL. Peixes afetados em manobras de usinas hidrelétricas. In: Loures RC, Godinho AL. Avaliação de risco de morte de peixes em usinas hidrelétricas. Belo Horizonte: Companhia Energetica de Minas Gerais; 2016. p.71-96.

- Rivas EJG, Pérez GR, Tundisi JG, Vammen K, Örmeci B, Forde M. Eutrophication: A growing problem in the Americas and the Caribbean. Braz J Biol. 2020; 80(3):688-89. https://dx.doi. org/10.1590/1519-6984.200001

- Roberto MC, Santana NF, Thomaz SM. Limnology in the Upper Paraná River floodplain: large-scale spatial and temporal patterns, and the influence of reservoirs. Braz J Biol. 2009; 69(2):717-25. https://doi. org/10.1590/S1519-69842009000300025

- Roberts TR, Baird IG. Traditional fisheries and fish ecology on the Mekong River at Khone Waterfalls in southern Laos. Nat Hist Bull Siam Soc. 1995; 43(2):219-62.

- Saint-Paul U, Bernardino G. Behavioural and ecomorphological responses of the neotropical pacu, Piaractus mesopotamicus (Teleostei, Serrasalmidae) to oxygen deficient waters. Exp Biol. 1988; 48(1):19-26.

- Saint-Paul U, Soares GM. Ecomorphological adaptation to oxygen deficiency in Amazon floodplains by serrasalmid fish of the genus Mylossoma. J Fish Biol. 1987; 32(2):231-36. https://doi. org/10.1111/j.1095-8649.1988.tb05356.x

- Salvo-Souza RH, Val AL. Pirarucu - o gigante vermelho das águas amazônicas. Ciência Hoje, 1990; 11(64):9-12. Available from: https://repositorio.inpa.gov.br/ handle/1/20322 
- Schisler GJ, Bergersen EP. Identification of gas supersaturation sources in the upper Colorado River, USA. Regul Rivers: Res Manage. 1999; 15(4):301-10. https://doi.org/10.1002/(SICI)10991646(199907/08)15:4\%3C301::AIDRRR521\%3E3.0.CO;2-7

- Shen X, Li R, Hodges BR, Feng J, Cai H, Ma X. Experiment and simulation of supersaturated total dissolved gas dissipation: Focus on the effect of confluence types. Water Res. 2019; 155:320-32. https://doi.org/10.1016/j. watres.2019.02.056

- Shen X, Li R, Huang J, Feng J, Hodges BR, Li K, Xu W. Shelter construction for fish at the confluence of a river to avoid the effects of total dissolved gas supersaturation. Ecol Eng. 2016; 97:642-48. https://doi.org/10.1016/j. ecoleng.2016.10.055

- Shrimpton JM, Randall DJ, Fidler LE. Assessing the effects of positive buoyancy on rainbow trout (Oncorhynchus mykiss) held in gas supersaturated water. Can J Zool. 1990; 68(5):969-73. https://doi. org/10.1139/z90-139

- Small K, Kopf RK, Watts RJ, Howitt J. Hypoxia, blackwater and fish kills: experimental lethal oxygen thresholds in juvenile predatory lowland river fishes. Plos One. 2014; 9(4):e94524. https://doi. org/10.1371/journal.pone.0094524

- Stroud RK, Bouck GR, Nebeker AV. Pathology of acute and chronic exposure of salmonid fishes to supersaturated water. In: Adams WA, Greer G, Desnoyers JE, Atkinson G, Kell GS, Oldham KB, Walkley J, editors. Chemistry and physics of aqueous gas solutions. Princeton: Electrochemical Society; 1975. p.435-49.

- Stroud RK, Nebeker AV. A study of the pathogenesis of gas bubble disease in steelhead trout (Salmo gairdneri). In: Fickeisen DH, Schneider MJ, editors. Gas bubble disease. Richland: Technical Information Center,Energy Research and Development Administration; 1976. p.66-71.

- Tang CY. Study of sediment impact on water Total Dissolved Gas Supersaturation. [D]. 487 Master thesis, Sichuan University, Chengdu. 2011.
- Tanner DQ, Bragg HM, Johnston MW. Total dissolved gas and water temperature in the lower Columbia River, Oregon and Washington, water year 2009: Qualityassurance data and comparison to waterquality standards [Internet]. Oregon: U.S. Geological Survey; 2003. Available from: https://doi.org/10.3133/OFR20091288

- Timmerman CM, Chapman LI. Hypoxia and interdemic variation in Poecilia latipinna. J Fish Biol. 2004; 65(3):63550. https://doi.org/10.1111/j.00221112.2004.00474.x

- Tundisi JG, Tundisi TM. Limnologia. São Paulo: Oficina de Textos; 2008.

- Ultsch GR. Ecology and physiology of hibernation and overwintering among freshwater fishes, turtles, and snakes. Biol Rev. 1989; 64(4):435-515. https://doi. org/10.1111/j.1469-185X.1989.tb00683.X

- Val AL, Almeida-Val VMF. Fishes of the Amazon and their environments. Physiological and biochemical features. Heidelberg: Springer; 1995.

- Val AL, Gomes KRM, Almeida-Val VMF. Rapid regulation of blood parameters under acute hypoxia in the Amazonian fish Prochilodus nigricans. Comp Biochem Physiol A Mol Integr Physiol. 2015; 184:125-31. https://doi.org/10.1016/j. cbpa.2015.02.020

- Val AL, Silva MNP, Almeida-Val VMF. Hypoxia adaptation in fish of the Amazon: a never-ending task. Afr Zool. 1998; 33(2):107-14. https://doi.org/10.1080/02541 858.1998.11448459

- Val AL. Conservação da biota aquática da Amazônia. REB. 2017; 6(11):79-89. https:// doi.org/10.14201/reb20196117989

- Wan H, Li J, Li R, Feng F, Sun Z. The optimal power generation operation of a hydropower station for improving fish shelter area of low TDG level. Ecol Eng. 2020; 147:105749. https://doi.org/10.1016/j. ecoleng.2020.105749

- Wang Y, Liang R, Li K, Li R. Tolerance and avoidance mechanisms of the rare and endemic fish of the upper Yangtze River to total dissolved gas supersaturation by hydropower stations. River Res Appl. 2020; 36(7):993-1003. https://doi.org/10.1002/ rra.3677 
- Wang Y, Liang R, Tuo Y, Li K, Hodges

B. Tolerance and avoidance behavior towards gas supersaturation in rock carp Procypris rabaudi with a history of previous exposure. N Am J Aquac. 2015; 77(4):478-84. https://doi.org/10.1080/15222 055.2015 .1059913

- Weitkamp DE, Katz M. A review of dissolved gas supersaturation literature. Tran Am Fish Soc. 1980; 109(6):659702. https://doi.org/10.1577/15488659(1980)109\%3C659:ARODGS\%3E2.0. $\mathrm{CO} ; 2$

- Weitkamp DE, Sullivan RD, Swant T, Santos J. Behavior of resident fish relative to total dissolved gas supersaturation in the lower Clark Fork River. Trans Am Fish Soc. 2003; 132(5):856-64. https://doi. org/10.1577/T02-025

- Weitkamp DE. Total dissolved gas supersaturation biological effects, review of literature 1980-2007. Bellevue: Parametrix; 2008.

- Winemiller KO, McIntyre PB, Castello L, Fluet-Chouinard E, Giarrizzo T, Nam S et al. Balancing hydropower and biodiversity in the Amazon, Congo, and Mekong. Science. 2016; 351(6269):128-29. https://doi. org/10.1126/science.aac7082
- Winemiller Ko. Patterns of variation in life history among South American fishes in seasonal environments. Oecologia. 1989; 81:225-41. https://doi.org/10.1007/ BF00379810

- Witt A, Magee T, Stewart K, Hadjerioua B, Neumann D, Zagona E, Politano M. Development and implementation of an optimization model for hydropower and total dissolved gas in the Mid-Columbia River system. J Water Resour Plan Manag. 2017; 143(10):04017063. https://doi. org/10.1061/(ASCE)WR.1943-5452.0000827

- Xue S, Kefeng L, Liang R, Cao L, Wang Y, Li Y, Feng J. In situ study on the impact of total dissolved gas supersaturation on endemic fish in the Upper Yangtze River. River Res Appl. 2019; 35(9):1511-19. https:// doi.org/10.1002/rra.3503

- Yuan YQ, Feng JJ, Li R, Huang YH, Huang JP, Wang ZH. Modelling the promotion effect of vegetation on the dissipation of supersaturated total dissolved gas. Ecol. Model. 2018; 386:89-97. https://doi. org/10.1016/j.ecolmodel.2018.08.016

\section{Neotropical Ichthyology}

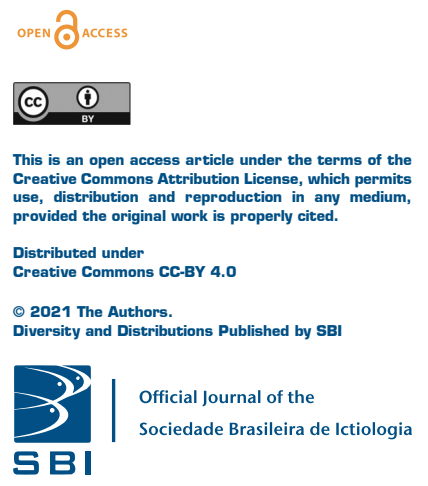

\section{AUTHOR'S CONTRIBUTION (ब}

Angelo Antonio Agostinho: Conceptualization, Supervision, Writing-original draft, Writing-review and editing.

Diego Correa Alves: Conceptualization, Writing-review and editing.

Luiz Carlos Gomes: Conceptualization, Writing-original draft, Writing-review and editing.

Rosa Maria Dias: Conceptualization, Investigation, Writing-original draft, Writing-review and editing.

Miguel Petrere Jr: Conceptualization, Investigation, Writing-review and editing.

Fernando Mayer Pelicice: Conceptualization, Investigation, Writing-original draft,

Writing-review and editing.

\section{ETHICAL STATEMENT}

Not applicable.

\section{COMPETING INTERESTS}

The authors declare no competing interests.

\section{HOW TO CITE THIS ARTICLE}

- Agostinho AA, Alves DC, Gomes LC, Dias RM, Petrere Jr M, Pelicice FM. Fish die-off in river and reservoir: A review on anoxia and gas supersaturation. Neotrop Ichthyol. 2021; 19(3):e210037. https://doi.org/10.1590/1982-0224-2021-0037 